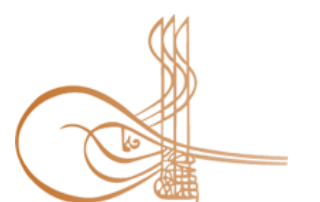

www.turkishstudies.net/social
Turkish Studies - Social Sciences

eISSN: 2667-5617

Research Article / Araștırma Makalesi

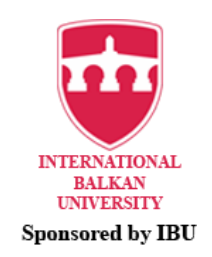

Sponsored by IBU

\title{
XIX. Yüzyıl Ortalarında Vize Kazası'nda Sosyo-Ekonomik Hayat
}

\author{
Socio-Economic Life In The Town Of Vize In Mid-19 ${ }^{\text {th }}$ Century
}

\author{
Tarı Özçelik* - Osman Durmaz ${ }^{* *}$
}

\begin{abstract}
After the proclamation of the Tanzimat Edict in the $19^{\text {th }}$ century, the Ottoman Empire tried to bring about a fair tax collection system. To achieve this aim, temettuat countings were conducted in several states. The data recorded in the temettuat registers are notable from a social and economic point of view. These registers, in addition to offering financial data, are important for providing useful information about the demographic structure, cultivated lands, animal husbandry and taxpayers. As a matter of fact, the temettuat countings carried out in Vize, a town in Kurklareli, in the $19^{\text {th }}$ century clearly show how the new economic reforms of the Tanzimat were reflected in socio-economic life in the region. In this study, six temettuat registers of countings carried out in 1845 in the central neighbourhoods of Vize in the Rumeli region are examined. As is well known, the countings in the Ottoman Empire were mostly carried out on a religious basis. This practice can also be observed in the Vize temettuat registers. In the light of these records, Muslim and non-Muslim neighbourhoods were identified and the social and economic status of the communities belonging to two different religions was determined in the mid- $19^{\text {th }}$ century. The economic system of the Ottoman Empire was based on agriculture and animal husbandry. The fact that the vast majority of households in the Vize temettuat registers make their living by farming proves that the situation was no different in Vize, a small Thracian town. As for the demographic structure of the town, it is estimated that almost half of the population was Muslim and the other half was non-Muslim. As it is understood from the occupation records in the Vize temettuat registers, in addition to farming, Muslims were mostly engaged in leather tanning while non-Muslims were mostly engaged in carpentry. For this reason, it can be deduced that the sub-branches of animal husbandry and forestry are important sources of income in Vize. There are twenty-five different types of occupations recorded in Muslim neighbourhoods while twenty-one different types of occupations were recorded for non-Muslims. Using the data obtained from the temettuat registers, this study provides information about the occupations in which both the Muslim and non-Muslim populations engage, the amount of the agricultural land they owned, the kinds and quantities of the crops they grew. The study also reveals the social and economic status of the Muslim and non-Muslim communities in the middle of the $19^{\text {th }}$ century by tracing the records on the amount of income these people earned and the taxes they paid.
\end{abstract}

\footnotetext{
* Dr. Öğr. Üyesi, Kırklareli Üniversitesi, Fen Edebiyat Fakültesi, Tarih Bölümü Asst. Prof. Dr., Kirklareli University, Faculty of Science and Letters, Department of History ORCID 0000-0001-7097-9558

tozcelik06@hotmail.com

*** Doktora Öğrencisi, Marmara Üniversitesi, Türkiyat Araştırmaları Enstitüsü, Yakınçağ Tarihi Bilim Dalı PhD. Student, Marmara University, Institute of Turkic Studies, Department History of Modern Age ORCID 0000-0003-1248-5546

osmandurmaz06@gmail.com

Cite as/ Atıf: Özçelik, T., Durmaz, O. (2020). XIX. yüzyıl ortalarında Vize Kazası'nda sosyo-ekonomik hayat. Turkish Studies - Social, 15(5), 2629-2654. https://dx.doi.org/10.47356/TurkishStudies.45218

Received/Gelis: 13 July/Temmuz 2020

Accepted/Kabul: 20 August/Ağustos 2020

Copyright $\subset$ INTAC LTD, Turkey
} 
Structured Abstract: After the proclamation of the Tanzimat Edict in the $19^{\text {th }}$ century, the Ottoman Empire tried to bring about a fair tax collection system. To achieve this aim, temettuat countings were conducted in several states. The data recorded in the temettuat registers are notable from a social and economic point of view. These registers, in addition to offering financial data, are important for providing useful information about the demographic structure, cultivated lands, animal husbandry and taxpayers. As a matter of fact, the temettuat countings carried out in Vize, a town in Kirklareli, in the $19^{\text {th }}$ century clearly show how the new economic reforms of the Tanzimat were reflected in socio-economic life in the region.

In this study, six temettuat registers of countings carried out in 1845 in the central neighbourhoods of Vize in the Rumeli region are examined. As is well known, the countings in the Ottoman Empire were mostly carried out on a religious basis. This practice can also be observed in the Vize temettuat registers. In the light of these records, Muslim and non-Muslim neighbourhoods were identified and the social and economic status of the communities belonging to two different religions was determined in the mid- $19^{\text {th }}$ century. The economic system of the Ottoman Empire was based on agriculture and animal husbandry. The fact that the vast majority of households in the Vize temettuat registers make their living by farming proves that the situation was no different in Vize, a small Thracian town. As for the demographic structure of the town, the population was approximately 2200 and it is estimated that almost half of the population was Muslim and the other half was non-Muslim. Since both the Greeks and the Bulgarians living in Vize were members of the same Orthodox Church until 1870, it is impossible to determine how much of the non-Muslim population was Greek or Bulgarian in the 1840s. Only after 1870 were the Bulgarians recorded as a separate ethnic group. As it is understood from the occupation records in the Vize temettuat registers, in addition to farming and animal husbandry, Muslims were mostly engaged in leather tanning while non-Muslims were mostly engaged in carpentry. For this reason, it can be deduced that the sub-branches of animal husbandry and forestry are important sources of income in Vize. There are twenty-five different types of occupations recorded in Muslim neighbourhoods while twenty-one different types of occupations were recorded for non-Muslims.

Another significant piece of information gathered from the Vize temettuat registers is about the agricultural lands owned by households in Vize. The farmland rate among Muslim neighbourhoods is $49 \%$ while this rate in non-Muslim neighbourhoods is $51 \%$. These very close rates tell us that both in Muslim and non-Muslim neighbourhoods almost half of the lands were not cultivated which leads us to the conclusion that the cultivated lands were sufficient to supply the needs of the town residents. In addition, cultivation of grapevines, which is still widespread in modern Thrace, comes to the fore as a significant agricultural activity with high added value. Besides grapes, other agricultural crops grown in the fields that belonged to the Muslim and non-Muslim locals were wheat, barley, rye, corn, vetch, linseed, beans and chickpeas. Crops called "alef', "kaplica" and "sehek" were also grown especially for animal feeding. According to the data gathered from the central neighbourhoods of Vize, the most widely grown crop was wheat, which was followed by barley and rye respectively. The amount of other crops that were only grown in non-Muslim neighbourhoods such as linseed, beans, chickpeas and vetch was relatively low. The amount of the "aşar" tax to be collected from all the households for the crops they grew was calculated as follows: The officers who carried out the counting determined a tax amount per unit depending on the type and amount of the crops and recorded it in the register. In the temettuat registers "kile", which corresponds to approximately 25 kilograms, and "kiyye", which is equivalent to 1,282 kilograms, were used as units of measurement. While "kile" was the unit of measurement for grains in general, "kiyye" was used only for grapes.

Women were rarely recorded as household heads in temettuat registers but it has been noticed that a few women were recorded as household heads in the Vize temettuat registers. These women took over the household responsibilities and provided for the household probably because their husbands had died or they had never got married and inherited their father's wealth. Three of the women were recorded in the registers as household heads and two of them as waqf administrators. Therefore, it can be deduced that some of the women living in Vize back at that time played a role in public life as either household leaders or waqf administrators.

In the central neighbourhoods of Vize, one of the income sources was animal husbandry. According to the figures recorded in the Vize temettuat registers, the number of cattle, sheep and goats owned by nonMuslim households was higher when compared to the number of the same type of animals owned by Muslim households. The reason for this might be that more non-Muslim household leaders were engaged in farming than Muslim household leaders, which in return must have automatically increased the number of animals

Turkish Studies - Social, 15(5) 
owned by non-Muslims. On the other hand, it has been identified that the households in Muslim neighbourhoods were mostly dealing with cattle breeding rather than sheep or goat breeding.

As for the income earned and taxes paid by the locals of Vize, average net annual household income in Muslim neighbourhoods was 1.071 kuruş while the figure for non- Muslim neighbourhoods was 758 kuruş. In other words, the amount of income earned by Muslims was 29,21\% higher than that of non-Muslims. On the other hand, average amount of taxes paid in Muslim neighbourhoods was 64 kuruş while it was 80 kuruş for non-Muslim neighbourhoods which means that non-Muslims paid 19,77\% more tax. It is also observed that the households in Muslim neighbourhoods which earn the highest amount of income pay 16 kuruş less tax than the households in non-Muslim neighbourhoods which earn relatively lower incomes. This difference was probably due to cizye taxes that non-Muslims had to pay.

Keywords: History, Vize, Kirklareli, Temettuat Registers, Tanzimat.

Öz: Osmanlı Devleti XIX. yüzyılda, Tanzimat'ın ilanından itibaren halktan adaletli bir vergi toplama sistemi getirmeye çalışmıştır. Bunun için çeşitli eyaletlerinde temettuât sayımlarını gerçekleştirmiştir. Temettuât defterlerine kaydedilen veriler, sosyal ve iktisadî açıdan dikkate değerdir. Bu sayımlar malî veri olma yanında demografik yapı, ekili dikili arazi, hayvan yetiştiriciliği ve vergi mükellefleri ile ilgili çeşitli bilgiler vermesi açısından da önem arz etmektedir. Nitekim günümüzde Kırklareli’ye bağlı Vize Kazası'nda gerçekleştirilen temettuât sayımlarında Tanzimat'la beraber getirilen yeni iktisadi usulün, sosyo-ekonomik hayata nasıl yansıdığı açıkça görülmektedir. Bu çalışmada 1845 yılında gerçekleştirilen ve Rumeli bölgesindeki Vize Kazası merkez mahallelerine ait 6 adet temettuât defteri incelenmiştir. Osmanlı Devleti'nin yaptığı sayımlar, çoğunlukla dini esasa göre yapılmıştır. Bunun bir örneği, Vize temettuât defterlerinde de görülmektedir. Ekonomik temeli tarım ve hayvancılık olan Osmanlı Devleti'nin tamamında olduğu gibi, küçük bir Trakya kasabası olan Vize'nin durumu da benzer şekildedir. Nitekim Vize temettuât defterlerindeki hanelerin büyük çoğunluğunun, çiftçilik ile geçimlerini sağlamaları bunu doğrulamaktadır. Kasabanın demografik yapısına göz atıldığında Vize merkezinin tahmini olarak hesap edilebilen ortalama nüfus oranı hem Müslüman hem de gayrimüslimler için neredeyse yarı yarıyadır. Ayrıca Vize temettuât defterlerindeki meslek kayıtlarından anlaşıldığına göre, Müslümanlar, çiftçiliğin yanında, en çok debbağlık (dericilik) yapmaktaydı. Gayrimüslimler ise çiftçiliğe ilaveten en çok dülgerlik (marangozluk) işiyle uğraşmıştır. Dolayısıyla hayvancılık ve ormancılığın yan kollarının Vize'de önemli bir gelir kaynağı olduğu ortaya çıkmaktadır. Müslüman mahallelerdeki nüfusa dair 25 farklı türde meslek kaydına rastlanmaktadır. Gayrimüslimlerde ise 21 farklı türde kaydın bulunduğu görülmektedir. Bu çalışma ile Temettuât defterlerinden elde edilen verilerle, gerek Müslüman nüfusun gerekse gayrimüslim nüfusun meşgul oldukları iş kolları, sahip oldukları tarım arazileri, yetiştirdikleri ürünlerin çeşit ve miktarları tespit edilmiştir. Ayrıca yine bu iki dine mensup olan Vize'deki ahalinin, elde ettikleri kazançlar ve ödedikleri vergilerle, XIX. yüzyıl ortalarındaki sosyal ve ekonomik durumları ortaya konulmaya çalışılmıştır.

Anahtar Kelimeler: Tarih, Vize, Kırklareli, Temettuât Defterleri, Tanzimat.

\section{Giriş}

Osmanlı Devleti'nde Tanzimat'la birlikte başlayan süreç, siyasi, sosyal ve iktisadî açıdan çok mühim bir dönemdir. Bu açıdan, Tanzimat'ın iktisadî yansımalarının hem Osmanlı sosyal hayatına etkisinin tahlil edilmesi, hem de Osmanlı şehir hayatının anlaşılması bakımından 1840'lı yıllarda gerçekleştirilen temettuât sayımları çok önemli arşiv kayıtlarıdır. Osmanlı Arşivi'nde bulunan 17.747 adet defterin ekserisi (BOA Rehberi, 2010: 248), bu çalışmaya konu olan defterlerde olduğu gibi 1844-45 tarihlidir. Çalışmanın esas konusuna geçmeden evvel XIX. yüzyılda Osmanlı Devleti’ndeki sayımların (tahrîrlerin) hangi amaçla gerçekleştirildiğine kısaca değinmek faydalı olacaktır.

Kaydetme ya da deftere geçirme gibi anlamlara gelen tahrîr (Sami, 2010: 383), Osmanlı Maliye Teşkilatında vergilerin ve bu vergileri verenlerin ismen tespiti için değişik dönemlerde farklı 
şehirlerde gerçekleştirilen sayımları ve bu sayımların kaydedildiği defterleri ifade etmektedir (Öz, 2010: 425).

Her devlet başta güvenlik ve savunma gibi çeşitli kamu hizmetlerini yerine getirmek için harcamalar yapmak ve bu harcamaları finanse edecek kaynakları bulmak zorundadır. Nitekim Osmanlı Devleti de kaynaklarını tespit amacıyla sayımlar yapmıştır (Tabakoğlu, 2012: 251). Bu çerçevede, XIX. yüzyılda temettuât sayımları gibi pek çok sayımlar gerçekleştirilmiştir (Adıyeke, 2000: 771).

Tanzimat'ın ilanı ile öteden beri halkı ve devleti zarara uğratan ve şikâyetlere sebep olan bir takım malî usullerin kaldırılacağına dair kararlar alınmış, bu kararlar çerçevesinde çeşitli isimlerle alınan vergilerin yerine herkesten geliri oranında tek bir verginin tahsil edilmesi esası benimsenmiştir (Özkaya ve Akyıldız, 2006: 19). Bu esasla getirilen temettuât vergisi; tüccar, esnaf, köylü, şehirli hane reislerinin yıllık kazançları üzerinden alınan verginin adıdır (Karamursal, 1989: 194; Doğan, 2014: 209; İpek, 2014: 4-5). Temettu' (تمتع) kelimesinin çoğulu olan temettuât, sözlükte kârlar, kazançlar anlamına gelmektedir (Redhouse, 1890: 592; Devellioğlu, 1996: 1073; Ayverdi, 2008: 3146).

Diğer taraftan, temettuât vergisini tespit edebilmek için memurları merkezden tayin edilen, bölgelerindeki nüfusu ve bu nüfusun malî gücünü belirlemek üzere muhassıllık teşkilatı kurulmuştur (Efe, 2002: 8). Ancak 1840 yılında başlanan ve muhassılların yükümlülüğünde yapılan sayımlarda vergilerin adil ölçülerde tarh ve tahsilinin mümkün olamayacağı anlaşılınca 1842 yılında muhassıllık uygulamasına son verilmiştir. Daha sonra Tanzimat yönetimi bu temel problemin, nüfusun vergi ödeme gücüne göre belirlenmesine imkân verecek yaygın bir tahrir faaliyetiyle çözümlenebileceği sonucuna ulaşmıştır. Bu sayımlar daha önceki mali sayımlardan farklı olarak merkezden gönderilen memurlar tarafından değil de sayımı yapılan idarî birimin muhtar ve imamı, gayrimüslimlerde ise kocabaş $1^{1}$ ve papazı tarafından ziraat müdürleri ve vekilleri nezaretinde yapılmıştır (Güran, 2000: 76; Öztürk, 2003: 289; Özkaya ve Aky1ldız, 2006: 19; Ortayl1, 2018: 33-36; Güran, 2019: 193-195). Bu çerçevede, yapılan sayımlarda elde edilen verilerin kaydedilmesi için defterler tutulmuştur. Bu kayıt defterlerine de temettuât defterleri adı verilmiştir (Yalçın, 2004; 13).

Temettuât defterlerinde, nüfusun yerleşim düzeni, zirai üretim durumu, hanelerin emlak ve arazilerinden elde ettikleri gelirleri ile vergilendirme konularını bulabilmek mümkündür (Kütükoğlu, 1995: 395-418; Sakin, 2008: 168; Bizbirlik ve Atar, 2009: 39-40). Vize Kazasına bağlı mahallelerin temettuât defterlerini değerlendirmeye geçmeden önce Vize tarihi hakkında kısaca bir bilgi vermek yerinde olacaktır.

\section{Eski Çağlarda Vize}

Vize Kazası'nın tarihçesine kısaca bir göz atıldığında, Vize'nin eski çağlardan beri yerleşim yeri olarak kullanıldığı görülmektedir. Nitekim Milattan Önce (M.Ö.) 1200’lerde Trak kavimlerinden Britanyalılar ve Frigler, burada birtakım krallıklar kurmuşlardır. Daha sonra, bölgeye M.Ö. IV. yüzyılda Persler hâkim olmuştur. Persleri takiben, M.Ö. 440 yılında Trakya, Atinalıların eline geçince Vize'de buraya bağlanmıştır. M.Ö. 350 yılında da Makedonya Kralı II. Filip, Vize ve civarına hâkim olmuştur. II. Filip'in oğlu Büyük İskender, M.Ö. 301 yılında Trakya'nın tamamını egemenliği altına almış, M.Ö. 72 yılında Trakya Krallığı kurulmuştur. M.Ö. 70 yılında ise Vize, bu krallığın başşehri olmuştur (Yarc1, 2005: 159).

\footnotetext{
${ }^{1}$ Kocabaşı, Rumeli'de köy ve mahallelerde yaşayan gayrimüslimlerin ileri gelenlerine verilen unvandır. Bunun yerine önceden "millet başı” tabiri de kullanılmıştır. Bu unvan, Anadolu ile Rumeli'deki Müslüman mahalle ve köylerinde muhtar şeklindedir. Tanzimat' tan sonra kocabaşı unvanı kaldırılarak genellikle muhtar tabiri kullanılmıştır. Ancak bu tabir gayrimüslimlerce benimsenmemiştir (Pakalın, 1993: 285).
} 
Son olarak Vize'de yapılan arkeolojik kazılarda, Milattan Sonra (M.S.) I. yüzyıla ait tümülüsler bulunmuştur (Büyük Larousse, 1986: 12241). Bu tümülüsler, bölgenin M.S. da yerleşim merkezi olarak kullanılmaya devam edildiğini göstermektedir.

\section{Bizans ve Osmanlı Dönemlerinde Vize}

Daha önceki dönemlerde Vison, Viza, Bizva ve Bizye gibi adlarla tanınan yöreye (Yurt Ansiklopedisi, 1983: 4820) ilk defa Bizanslılar tarafindan "Vize" dendiğini söylemek yanlış olmaz. İmparator I. Konstantin 338 yılında Vize'yi ele geçirmesiyle bölgede başlayan Bizans hâkimiyeti, 1363 yılına kadar devam etmiştir. 886-912 yılları arasında imparator olan IV. Leon döneminde bölge, önemli bir dinî merkez olarak öne çıkmış, Bizans yönetimi burada bir de başpiskoposluk tesis etmiştir (Yarc1, 160). Özellikle Bizans döneminde şehrin ana kilisesi olarak tahmin edilen Ayasofya, Trakya'nın en önemli dinsel yapılarından birisidir. Öte yandan XIV. yüzyılda Osmanlıların bölgeye hâkimiyetlerinden sonra ise bu kilise camii olarak düzenlenmiştir (Büyük Larousse, 12241; Eyice, 1991: 223).

Vize'nin Osmanlılar tarafından fethedilmesi I. Murat zamanında gerçekleşmiştir. Papa'nın Venedik'e gönderdiği mektupta, Osmanlı'nın Trakya'daki zaferlerinden söz edilmiş ve bu zaferlerin Bizans ve Sırp Krallıklarına karșı kazanılmıș bir zafer olduğu vurgulanmıștır. Papa'nın söz ettiği bu zaferler, Kırkkilise-Vize kalelerinin Osmanlılar tarafindan fethedilmesidir (İnalckk, 2011: 102). 1361 yılında Edirne'nin fethedilmesi ve bölgede Osmanlı akınlarının artması (İnalcık, 77-81) ve son olarak Vize Kalesinin de fethedilmesiyle birlikte Vize şehri Osmanlı'nın kontrolüne geçmiştir (1363).

Bu tarihten itibaren Osmanlı idaresi altında olan Vize'nin XV. yüzyılın ortalarında Osmanlı idarî yapısında Rumeli Eyaletine bağlı üç sancağından biri olduğu anlaşılmaktadır (Birken, 1976: 59; Gökbilgin, 2007: 7). Evliya Çelebi'nin “Seyahatname"sine göre XVII. yüzyılda Özü Eyaletine bağlı bir sancak hüviyetinde olan Vize (Birken, 59), temettuât defterlerinde yazıldığına göre, XIX. yüzyılın ortalarında Edirne Eyaletine bağlanmıştır (BOA, ML.VRD.TMT, d. 06551, vr. 1; d. 06541; Sezen, 2017: 792). Günümüzde ise Kırklareli’nin bir ilçesidir.

\section{Temettuât Defterlerine Göre Vize Kazası'na Bağlı Mahallelerin İdari Yapısı ve Nüfusu}

Bu çalışmanın konusu olan Vize Kazası'na ait BOA'da 6 adet temettuat defteri mevcuttur. $\mathrm{Bu}$ mahallelere ait defterler hakkındaki bilgiler aşağıdaki tabloda gösterilmiştir:

Tablo 1: Vize Kazasına ait Temettuât Defterlerinin Arşiv Bilgileri

\begin{tabular}{llll}
\hline $\begin{array}{c}\text { Sira } \\
\text { No }\end{array}$ & \multicolumn{1}{c}{ Mahallenin Adı } & \multicolumn{1}{c}{$\begin{array}{c}\text { Toplam Varaka (vr.) } \\
\text { Sayısı }\end{array}$} & Arşivdeki Defter Kodu \\
\hline $\mathbf{1}$ & Derûn-1 Kal'a Mahallesi & 27 & ML.VRD.TMT.d.06551 \\
\hline $\mathbf{2}$ & Seyyid Kasım Mahallesi & 21 & ML.VRD.TMT.d.06541 \\
\hline $\mathbf{3}$ & Hacı Şâzi Mahallesi & $13^{1 \text { vr. bos }}$ & ML.VRD.TMT.d.06533 \\
\hline $\mathbf{4}$ & Yenice Müsellem Mahallesi & 7 & ML.VRD.TMT.d.06548 \\
\hline $\mathbf{5}$ & Manavlar Mahallesi & $11^{1 \text { rr. bos }}$ & ML.VRD.TMT.d.06554 \\
\hline $\mathbf{6}$ & Kazada bulunan âyânlar & & ML.VRD.TMT.d.06553 \\
\hline
\end{tabular}

Defterlere göre kazada beş Müslüman Mahallesi bulunmaktadır. Bunlar; Derûn-1 Kal'a Mahallesi, Seyyid Kasım Mahallesi, Hacı Şâzi Mahallesi, Yenice Müsellem Mahallesi ve Manavlar Mahallesi'dir. Gayrimüslim mahallelerin hepsi ise bir defterde yer almaktadır. Toplamda üç mahallenin yanında Kıptîler ile Esnaflar da aynı deftere kaydedilmiştir. Bu üç mahallenin isimleri;

\footnotetext{
2 Defterin ilk varakasında “derûn-1 kasabada mütemekkin [yerleşmiş] âyânın defter-i emlâkı" yazmaktadır. Defter incelendiğinde toplam 5 ayrı başlıkta kaydedildiği görülmektedir. Bunlar, Karşı Mahalle (Zimmîyân), Bulaca Mahallesi (Zimmîyân), Yazı Mahalle (Zimmîyân), Yanyalı olup Vize'de esnaflık yapanlar ve Kıptiyân şeklindedir. Çalışmamızda bu defter "Gayrimüslim Mahallelerin Sosyo-Ekonomik Durumu" başlığı altında değerlendirilecektir.
} 
Karşı Mahalle, Bulaca Mahallesi ve Yazı Mahallesi şeklindedir (BOA, ML.VRD.TMT, d. 06553, vr. $2,10,30,46,47)$.

Defterlerin sonunda Müslüman mahalleleri için "İmam der-Kaza-y1 Vize”, "Muhtar-1 Evvel Kaza-yı Vize" ve "Muhtar-1 Sâni Kaza-yı Vize" şeklinde mühürler bulunmaktadır (BOA, ML.VRD.TMT, d. 06551, vr. 27; d. 06541, vr. 20; d. 06533, vr. 14; d. 06548, vr. 7; d. 06554, vr. $10)$.

Gayrimüslimlerin kaydedildiği defterde ise "Der-Kaza-y1 Vize Millet-i Rumîyân Muhtar-1 Evvel", "Der-Kaza-yı Vize Millet-i Rumîyân Muhtar-1 Sâni” şeklinde ve bir papaza ait olduğu muhtemel Rumca yazılmış mühür bulunmaktadır (BOA, d. 06553, vr. 47). Bu mühürlerin imza yerine kullanıldığını söylemek mümkündür. Öte yandan bu mühürler mahallelerin idari yapısı hakkında da bilgi vermektedir. Nitekim bir mahallenin iki muhtarla idare edildiği anlaşılmaktadır. Ayrıca din görevlilerinin de mahallelerde idarî görevli olduğunu belirtmek yanlış olmaz (Küçükaşçı ve Yel, 2003: 323-326; Çadırc1, 2013: 39-40).

Ayrıca, mahallelerin nüfusu konusunda temettuât defterlerinden tahmine dayalı olarak bir yorum yapılabilir. Zira söz konusu sayımlar çoğunlukla malî ve askerî amaçla gerçekleştirildiği için tüm nüfusu gösteren kesin rakamlara ulaşmak mümkün değildir (Doğan, 211).

Temettuât defterlerinde, sadece mahallelerdeki hane sahiplerinin isimleri kaydedilmiştir. Genellikle erkek hane reislerinin yazıldığ 1 kayıtlarda, bazen kadınlar da hane reisi olarak karşımıza çıkmaktadır. Derûn-1 Kal'a ve Seyyid Kasım Mahallelerine ait kayıtlarda 3'ü hane reisi, 2'si vakıf mütevellisi olmak üzere 5 kadın ismine rastlanılmıştır.

Yukarıda da bahsedildiği üzere, temettuât defterlerindeki sayımlar hane bazında olduğundan, mahallelerin nüfusuna dair kesin bir yargıda bulunmak yanlış olur. Fakat Ömer Lütfi Barkan'ın tespitine göre her hane 5 kişiden ibaret olduğu genel kabul görmüştür. Bundan başka XIX. yüzyılda Balkanlar'dan, Kafkasya'dan Kuzey Karadeniz ülkelerinden ve diğer yerlerden Anadolu'ya yönelik göçmenlere ait listelerdeki nefer ve hane verilerinin incelenmesinden, bu yüzyılda bir hanedeki nüfus sayısının 4,11 ile 4,17 olduğu ortaya çıkmaktadır. Bu katsayı yörelere göre değişmekte, bizzat devlet adamları tarafından bile aynı devirde bazen 5, bazen ise 3 olarak hesaplanmaktadır (Göyünç, 1997: $552-553)$.

$\mathrm{Bu}$ çalışmada, temettuât defterlerindeki her bir hanede ortalama 5 nüfusun olduğu varsayılmıştır. Böylece mahallelerin nüfusuna ilişkin aşağıdaki tablo ortaya çıkmaktadır.

Tablo 2: Vize Kazasında Müslüman ve Gayrimüslim Hane Sayısı ve Tahmini Nüfus

\begin{tabular}{lcc} 
Mahalleler & Hane Sayısı & $\begin{array}{c}\text { Tahmini Nüfus } \\
\text { (Hane x 5) }\end{array}$ \\
\hline Müslümanlar & 218 & 1.090 \\
\hline Gayrimüslimler & 222 & 1.110 \\
\hline Toplam & 440 & 2.200 \\
\hline
\end{tabular}

Tablo 2'ye bakıldığında 218 haneye sahip Müslüman mahallelerinde tahmini nüfus 1.090, 222 haneye sahip olan Gayrimüslim mahallelerinde ise 1.110'dur. Toplamda Vize merkezinde 2.200 nüfus bulunmaktadır.

Buna göre Müslüman nüfus oranı \%49,55; Gayrimüslim oranı ise \%50,45’tir. Dolayısıyla kaza merkezinde Müslüman/Gayrimüslim oranı birbirine çok yakındır. 


\section{Temettuât Defterlerine Göre Vize Kazasına Bağlı Mahallelerde Sosyo-Ekonomik Durum}

Temettuât defterlerinde, sosyal ve ekonomik hayata dair bazı bilgileri bulabilmek mümkündür. Bu bilgiler, hane reislerinin; mesleklerini, elde ettikleri mahsuller ile miktarlarını, ayrıca tasarruf ettikleri toprak miktarı ve niteliğini ve yıllık kazançlarına göre ödedikleri vergileri içermektedir. Buna ilaveten hanelerin sahip olduğu hayvan miktarları ve bu hayvanlardan elde ettikleri gelirler de bu kayitlarda mevcuttur.

Değerlendirmeye geçmeden önce, defterlerin iki ayrı kısımda incelendiğini belirtmek gerekir. İyi bilindiği üzere Osmanlı Devleti'nin yaptığı sayımlar, çoğunlukla dini esasa göre yapılmıştır. Bunun bir örneği, Vize'nin temettuât defterlerinde görülmektedir. Nitekim gayrimüslimlerle ilgili olan kısmın son sayfasında mahallenin idaresinden sorumlu muhtarların mühürlerinde, daha evvel de belirtildiği üzere "Der-Kaza-yı Vize Millet-i Rumîyân ..." yazmaktadır. $\mathrm{Bu}$ ifadeyle, defterin gayrimüslimlerin yaşadığı mahallelere ait olduğu belirlenebilmektedir. Burada belirtilmesi gereken önemli bir husus da Millet-i Rûmiyân tabirinin hem Rumları hem de Bulgarları ihtiva ediyor olmasıdır. Zira 1870 yılına kadar hem Rumlar hem de Bulgarlar aynı Ortodoks kilisesine bağlı olduklarından her iki millet de belgelerde Millet-i Rûmiyân olarak kaydedilmiștir. Ancak bu tarihten sonra Bulgarlar ayrı bir etnik unsur olarak kayıtlara geçecektir. Dolayısıyla 1840'lı yıllarda Vize'de yaşamakta olan gayrimüslimlerin ne kadarının Rum ne kadarının Bulgar olduğunu belirleyebilmek mümkün değildir. Yani buradaki Rum ibaresi Bulgarları da içine almaktadır. Diğer taraftan, Vize'deki Müslüman haneler, hane reislerinin isimlerinden kolayca tespit edilebilmektedir. Değerlendirme bu hususlar çerçevesinde yapılmış ve iki farklı dine mensup hanelerin XIX. yüzyıl ortalarındaki sosyal ve ekonomik durumları ana hatlarıyla belirlenmeye çalışılmıştır.

\section{Müslüman Mahallelerin Sosyo-Ekonomik Durumu}

\subsection{Hane Reislerinin Tahlili}

Müslüman mahallelerine ait temettuât defterlerinde hane reislerinin isimleri, baba isimleriyle birlikte kaydedilmiştir. Çoğunlukla Arapça'daki “bin” (oğlu) kelimesinin kullanıldığı görülmektedir (BOA, ML.VRD.TMT, d. 06551; d. 06541; d. 06533; d. 06548; d. 06554). Örneğin, Derûn-1 Kal'a Mahallesi'nin temettuât defterinde 1 numaralı hanenin reisi Ferhat Bey; "Ferhad Bey bin Ahmet

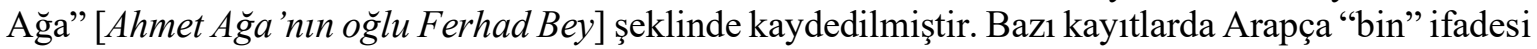
kullanılmayıp, Türkçe olarak "oğlu" ifadesinin de kullanıldığı görülmektedir. Aynı mahallenin temettuât defterinde iki kişinin ortaklığında bir hane reisi kaydı mevcuttur. 3 numaralı hanede yer alan Ahmed Ağazade Bekir Ağa ve Biraderi Şükrü Efendi tek bir hanenin iki ortağı olarak defterde kaydedilmiştir.

Vize'ye bağlı bütün mahallelerde en yüksek kazanca sahip olan hane reisi Ferhat Bey'dir. Derûn-1 Kal'a Mahallesi'nin temettuât defterinde çiftlik sahibi olarak kayıtlı Ferhad Bey, kazancını Vize'de bulunan iki çiftliğinden temin etmiştir. Bunlardan biri kaza merkezinde bulunan çiftliği, diğeri de yine aynı kaza sınırları içerisinde olan Sinanlı Çiftliğidir. Vize'nin en zengini olarak kayıtlara geçmiş olan Ferhat Bey'in yıllık gelirine göz atıldığında diğer hanelerin gelirleri ile kendisi arasında çok büyük bir fark olduğu görülecektir.

Defterlerde genellikle hane reisi olarak kadınların kaydedilmesi az rastlanan bir durumdur. Buna rağmen, Vize temettuât defterlerinde birkaç kadın hane reisine rastlanmıştır. Bu hane reisleri muhtemelen eşleri vefat etmiş ya da hiç evlenmeyip babalarından kalan miras ile hanelerindeki sorumlulukları üzerine alıp geçimlerini sürdüren kadınlardır. Daha önce de değinildiği üzere, iki mahallede beş kadın ismi bulunmaktadır. Bu kadınların üçü hane reisi, ikisi ise vakıf mütevellisi olarak kaydedilmiştir. Kadın hane reisleri Derûn-1 Kal'a Mahallesinde Hatice Hanım binti [kızı] Ahmet Ağa (BOA, ML.VRD.TMT, d. 06551, vr. 1, hane [hn.] 4), Hatice Hatun (BOA, ML.VRD.TMT, d. 06551, vr. 23, hn. 81) ve Seyyid Kasım Mahallesinde Ayşe Hatun (BOA, 
ML.VRD.TMT, d. 06541, vr. 19, hn. 54)'dur. Hatice Hanım binti Ahmet Ağa olarak kaydedilen hane reisine dair kayıtlarda herhangi bir meslek kaydına rastlanılmamakla birlikte, hane reisinin sadece bağ ve çayır arazilerinden elde ettiği kazançlar yer almaktadır. Yine aynı mahallede 81 numaralı hanede kayıtlı olan Hatice Hatunun, bir kahvehanenin 2/3'ü ve bir değirmenin de 2/9 hissesine sahip olduğu görülmektedir. Ayrıca 1 dönümlük bağ arazisine de sahip olan Hatice Hatun bütün bunlardan elde ettiği kazançlarla geçimini sağlayıp, vergisini vermiştir. Seyyid Kasım Mahallesindeki Ayşe Hatun'a dair kayıtlarda ise, Hacı Hasan'ın zevcesi olduğu ve oğullarının yardımlarıyla hayatını sürdürdüğü anlaşılmaktadır. Hane reisi kadınların haricinde, vakıf mütevellisi olan iki de kadın, defterlerde göze çarpmaktadır. Vakıf mütevellisi olan bu kadınlardan biri, Terkos Kazası'nın Istranca Köyü'nde ikamet eden ve Vize'de bulunan İskender Paşa Vakfi'nın mütevellisi Ayşe Hanım'dır. Diğeri ise, Pınarhisar Kazası'nda ikamet eden, Üveys Bey ve Turşah Hatun Vakfı'nın idarecisi olan Zeliha Hatun'dur (BOA, ML.VRD.TMT, d. 06541, vr. 26). Görüldüğü üzere, o yıllarda Vize'de yaşayan bazı kadınlar, vakıf yöneticisi olarak sosyal hayatta öne çıkmaktadır.

Öte yandan temettuât defterlerinde, Müslüman hane reislerinin, unvanlarıyla birlikte kaydedildiği görülmektedir. Bunlar genellikle "molla, imam, hafız, ağa, efendi ve çavuş" şeklindedir. Hane reislerinin kazadaki tanınan unvanlarıyla kaydedilmesi, şahısların meşgul oldukları mesleklerle ilgili de bilgi vermektedir. Örneğin, Hacı Şâzi Mahallesinin temettuât defterinde 37 numaralı hanedeki Yusuf'un askerlik mesleğinden emekli olduğu bilgisi kaydedilmekle birlikte, "Çavuş" unvanıyla kaydedilmiştir (BOA, ML.VRD.TMT, d. 06533, vr. 14). Yine aynı şekilde, Derûn-1 Kal'a Mahallesine ait temettuât defterinde 89 numaralı hane reisi Hafiz İsmail Efendi'nin, imam olduğu belirtilerek, "Hafiz" unvanıyla kaydedilmiştir (BOA, ML.VRD.TMT, d. 06551, vr. 26, hn. 89).

\subsection{Hane Reislerinin Meslekleri ve Kazançları}

Temettuât defterlerinde hane reislerinin ne işle meşgul oldukları, hane reislerinin isimlerinden önce yazılmıştır. Örneğin, Yenice Müsellem Mahallesi'nin temettuât defterinde 2 numaralı hane reisinin mesleği "erbab-1 ziraâtten idüğü" şeklinde kaydedilmiş olup, buradan bu hane reisinin çiftçi olduğu anlaşılmaktadır (BOA, ML.VRD.TMT, d. 06548, vr. 2, hn. 2). Diğer tüm temettuât defterlerinde de benzer şekilde kayitların mevcut olduğu görülmektedir.

Müslüman mahallelerine ait olan kayıtlarda 25 farklı türde meslek kaydının olduğu ortaya çıkmaktadır. Aşağıdaki tabloda bu meslek kayıtlarına dair bilgiler yer almaktadır. 
Tablo 3: Müslüman Mahallelerdeki Hane Reislerinin Meslekleri ve Gelirleri

\begin{tabular}{|c|c|c|c|c|}
\hline \multirow{2}{*}{$\begin{array}{l}\ddot{\ddot{z}} \\
\dddot{\pi} \\
\ddot{n}\end{array}$} & \multirow[b]{2}{*}{ Meslek Adı } & \multicolumn{2}{|c|}{ Kuruş Cinsinden } & \multirow{2}{*}{$\begin{array}{c}\text { Hane } \\
\text { Reisi } \\
\text { Sayıs }\end{array}$} \\
\hline & & $\begin{array}{c}\text { En Düşük } \\
\text { Kazanç }\end{array}$ & $\begin{array}{c}\text { En Yüksek } \\
\text { Kazanç }\end{array}$ & \\
\hline 1 & Çiftlik Sahibi & --- & 46.727 & 1 \\
\hline 2 & Çiftçi & 132 & 5.145 & 56 \\
\hline 3 & Kâtip/Jurnal Kâtibi & 600 & 1.200 & 2 \\
\hline 4 & Rençber & 789 & 1.094 & 5 \\
\hline 5 & Zaviyedâr & 350 & 900 & 2 \\
\hline 6 & Kasap & --- & 400 & 1 \\
\hline 7 & Zahire Tüccarı & 300 & 400 & 2 \\
\hline 8 & Nakliyeci & 100 & 400 & 5 \\
\hline 9 & At/Hayvan Bakıcısı & 190 & 320 & 2 \\
\hline 10 & Mutafçı & 100 & 300 & 10 \\
\hline 11 & Debbağ & 100 & 300 & 35 \\
\hline 12 & Nalbant & 200 & 300 & 3 \\
\hline 13 & Etbâ (Uşaklar) & 150 & 350 & 9 \\
\hline 14 & İmam & 150 & 300 & 5 \\
\hline 15 & Askeriye Emeklisi & --- & 300 & 1 \\
\hline 16 & Kahveci & 120 & 250 & 5 \\
\hline 17 & Sığırtmaç (Sığır Çobanı) & 150 & 250 & 4 \\
\hline 18 & Tüfekçi & 40 & 250 & 2 \\
\hline 19 & Hizmetkâr & 50 & 210 & 13 \\
\hline 20 & Berber & 100 & 200 & 6 \\
\hline 21 & Helvacı & 100 & 200 & 2 \\
\hline 22 & Korucu & --- & 200 & 1 \\
\hline 23 & Duhan Kapıcisı & --- & 150 & 1 \\
\hline 24 & Bağ Bekçisi & 150 & 150 & 2 \\
\hline 25 & Müezzin & --- & 100 & 1 \\
\hline Tol & am & 3.871 & 60.396 & 176 \\
\hline
\end{tabular}

Tabloda meslek sahibi olan hane reisi sayısı gösterilmekle birlikte, mesleklerden senelik elde edilen en düşük ve en yüksek kazançlar da belirtilmiştir. Ekonomisi tarıma dayalı Osmanlı Devleti'nin küçük bir kasabası olan Vize ahalisinin de en önemli geçim kaynağı tarımdır. Tabloda görüleceği üzere 176 hanenin, 56 hanesi çiftçilik ile uğraşmaktadır. Yine tabloya bakıldığında çiftçilikten sonra en çok debbağllk ${ }^{3}$ mesleği ile uğraşanlar gelmektedir. Bunu 10 hane ile mutafçıllık ${ }^{4}$ takip etmektedir. Vize'deki tüm mahallelerde debbağlık ve mutafçılık işi ile uğraşan ve sayıları hiç de az olmayan hane reisleri olduğundan hareketle, hayvancıllğın yan kollarının da oldukça önemli bir gelir kaynağı olduğunu söylemek gerekir. Bir başka değerlendirilmesi gereken husus da teb'a taifesi olarak kaydedilen hane reisleridir. Teb'a ya da etbâ, sözlükte uşak ve hizmetkâr anlamına gelmektedir (Sami, 68; Pakalın, 567; Devellioğlu, 272). Bu taifeden olan hane reisleri tespit edilebildiği kadarıyla çiftçilik yapmayıp, yalnız hizmetkârlık işiyle uğraşmaktadır. Etbâ taifesi olarak toplamda 9 hane reisinin kayd1 bulunmakla birlikte, hane reislerinin 6's1 Derun-1 Kal'a Mahallesindedir. Etbâ olarak kaydedilen hane reisleri, muhtemelen bu mahallede bulunan Ferhat Bey'e ait çiftlikte uşak olarak çalışmış olmalıdırlar (BOA, ML.VRD.TMT, d. 06551, hn. 38, 46, 49, $72,75,83$; d. 6533, hn. 30; d. 6554, hn. 22; d. 6541, hn. 53).

\footnotetext{
${ }^{3}$ Dericilik ișiyle alakalı olan bir meslek koludur (Sami, 602).

${ }^{4}$ Sözlükte, mutablık ya da mutafçılık olarak geçmektedir. Mutafçı, keçi kılından örülmüş bez satan kimseye denmektedir (Sami, 1425).
} 
Müslüman mahallelerine ait temettuât defterlerinden, Seyyid Kasım Mahallesi'ne ait olan defterde, 28 ve 29 numaralı hanelerde yaşayan hane reislerinin Vize'de bulunan Şeyh Bâli Zaviyesinde görevli zaviyedâr oldukları bilgisi kaydedilmiştir (BOA, ML.VRD.TMT, d. 06541, vr. 2, hn. 28, 29). Buradan da Vize'de Seyyid Kasım Mahallesinde bir zaviye bulunduğu anlaşılmaktadır.

Son olarak bir mesleğin ne kadar gelir getirdiğinden bahsetmek gerekir ise, Vize'de bir çiftçinin en yüksek yıllık kazanc1 5.145 kuruş olup, bir Rençber'in ise 1.094 kuruştur. Ayrıca kasap, zahire tüccarı ve nakliyecinin en yüksek kazanc1 400 kuruş, etbâ taifesinden bir hizmetkârın 350 kuruş, hayvan bakıcısının 320 kuruş, imam, nalbant, mutafçı ve debbağın 300 kuruş, kahveci, sığırtmaç ve tüfekçinin 250 kuruş, berber, korucu ve helvacının 200 kuruş, duhan kapıcısı ve bağ bekçisinin 150 kuruş, müezzinin ise senelik en yüksek kazanc1 100 kuruştur.

\subsection{Mahallelerdeki Tarım Arazileri ve Hanelerin Kazançları}

Tüm mahallelere ait defterlerde araziler "Mezrû (Ekilmiş) Tarla", "Gayrı Mezrû (Ekilmemiş/Nadasa Bırakılmış) Tarla", "Çayır" ve "Bağ-Bahçe" şeklinde yazılmıştır. Aşağıdaki tabloda mahallelerde yaşayan hanelerin sahip oldukları bu arazilerin dönüm cinsinden (yaklaşık 1000 metrekare) miktarları gösterilmektedir.

Tablo 4: Müslüman Mahallelerdeki Tarım Arazilerinin Miktarları (Dönüm)

\begin{tabular}{|c|c|c|c|c|c|c|c|c|}
\hline \multirow[t]{2}{*}{$\begin{array}{r}\text { Mahalle Adı } \\
\text { (Hane Sayısı) }\end{array}$} & \multicolumn{4}{|c|}{$\begin{array}{l}\text { Mahallelerdeki Arazilerin } \\
\text { Çeşitlerine Göre Toplamı }\end{array}$} & \multicolumn{4}{|c|}{$\begin{array}{c}\text { Hane Başına Düşen Ortalama Arazi } \\
\text { Miktarı }\end{array}$} \\
\hline & $\begin{array}{c}\text { Mezrû } \\
\text { (Ekilmiş) } \\
\text { Tarla }\end{array}$ & $\begin{array}{c}\text { Gayrı Mezrû } \\
\text { (Ekilmemiş) } \\
\text { Tarla }\end{array}$ & Çayır & $\begin{array}{l}\text { Bağ- } \\
\text { Bahçe }\end{array}$ & $\begin{array}{c}\text { Mezrû } \\
\text { (Ekilmiş) } \\
\text { Tarla }\end{array}$ & $\begin{array}{c}\text { Gayrı Mezrû } \\
\text { (Ekilmemiş) } \\
\text { Tarla }\end{array}$ & Çayır & $\begin{array}{l}\text { Bağ- } \\
\text { Bahçe }\end{array}$ \\
\hline Derûn-ı Kal'a (90) & 628 & 765 & 31,5 & 91,75 & 6,98 & 8,50 & 0,35 & 1,02 \\
\hline Seyyid Kasım (51) & 534 & 378,5 & 69 & 49,25 & 10,47 & 7,42 & 1,35 & 0,97 \\
\hline Hacı Şâzi (37) & 580 & 394 & 1,5 & 34,25 & 15,68 & 10,65 & 0,04 & 0,93 \\
\hline Yenice Müsellem (14) & 129 & 89 & 15,5 & 24,25 & 9,21 & 6,36 & 1,11 & 1,73 \\
\hline Manavlar (26) & 207 & 164 & 15 & 14,5 & 7,96 & 6,31 & 0,58 & 0,56 \\
\hline Toplam: & 2078 & 1790,5 & 132,5 & 214 & 50,30 & 39,24 & 3,43 & 5,20 \\
\hline
\end{tabular}

Tablo 4 incelendiğinde, en çok ekili tarla, 90 hanenin bulunduğu Derûn-1 Kal'a Mahallesinde bulunmaktadır (628 dönüm). Bunun devamında en çok ekili tarlaların bulunduğu mahalleler sırasıyla, Hacı Şâzi Mahallesinde 580, Seyyid Kasım Mahallesinde 534, Manavlar Mahallesinde 207 ve Yenice Müsellem Mahallesinde ise 129 dönümdür. En az ekili tarlanın Yenice Müsellem Mahallesinde olduğu görülmektedir. Ekilmemiş tarlaların dönüm miktarlarının da yine aynı sıralamada olduğu anlaşılmaktadır. Çayır arazilerine bakıldığında, diğer dört mahallenin toplamından daha fazla çayıra sahip mahalle, Seyyid Kasım Mahallesidir. Bağ ve bahçe arazisinde de en fazla miktarda dönümü bulunan mahallenin yine Derûn-1 Kal'a Mahallesi olduğu açıkça görülmektedir. Tabloya dair genel bir değerlendirme yapıldığında, Derûn-1 Kal'a Mahallesi'nin en fazla araziye sahip olduğu sonucu ortaya çıkmaktadır. 
Vize'de Müslüman mahallelerine ait arazi çeşitlerinin genel dağılımlarının yüzdelik oranları aşağıdaki grafikte gösterilmektedir.

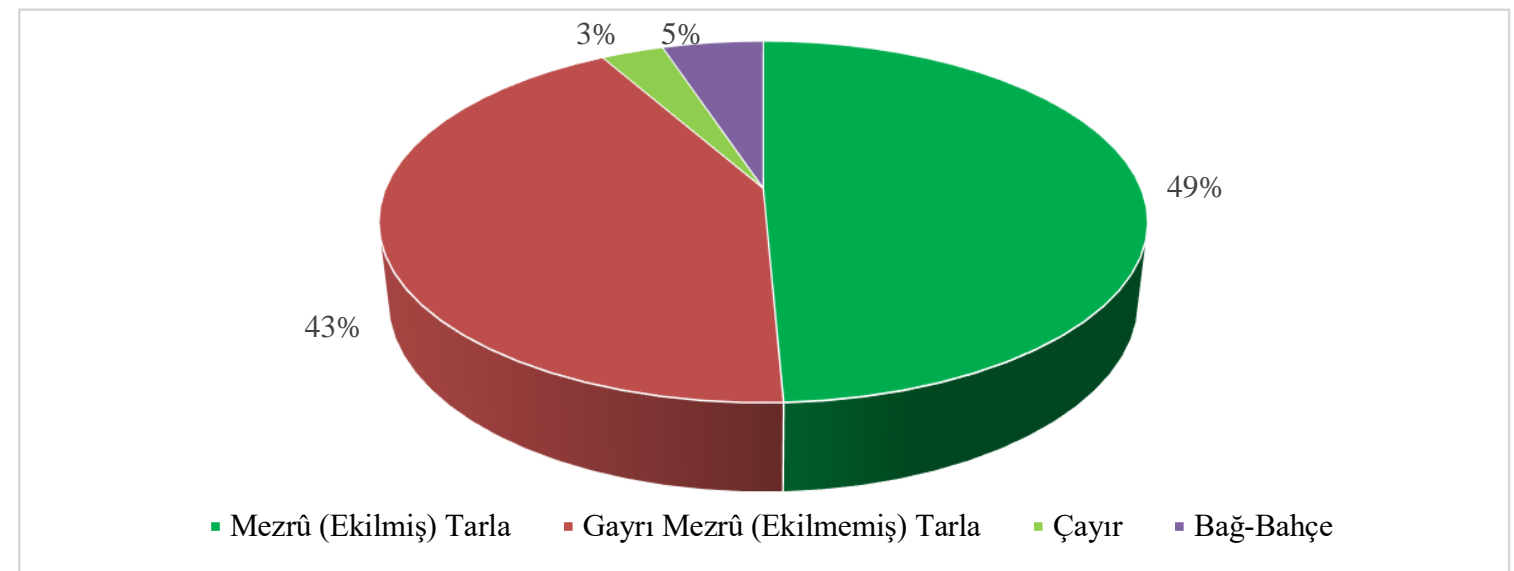

Grafik 1: Müslüman Mahallelerin Sahip Oldukları Tarım Arazilerin Yüzdelik Oranları

Grafikteki arazilerin dağılımı incelendiğinde ekilmiş tarla arazisinin oranı diğer arazi çeşitlerine göre yüksektir. Bu oranları, ekilmemiş tarla, bağ-bahçe ve çayır arazileri takip etmektedir.

Ayrıca geçmişten günümüze Trakya bölgesinde yapılan üzüm yetiştiriciliği o dönemde Vize'de de yapılmaya devam ediyordu. Bağlarda yetiştirilen üzüm Kırklareli ve çevresi için önemli bir üründü. Grafikte de görüldüğü üzere, bütün araziler içerisinde $\% 5$ 'lik bir orana sahip olan bağlarda yetiştirilen üzümler, daha sonra bahsedileceği üzere, oldukça iyi gelir getiren üründür.

Neticede tarla arazilerinin toplam oranı \%92'dir. Bu oranın \%49'unu ekilmiş tarlalar oluşturmaktadır. Geriye kalan \%43'lük bir oranda da ekilmemiş tarlalar bulunmaktadır. Bu noktada çoğunluğu çiftçi olan Müslüman ahalinin ihtiyaçları nispetinde tarlalarını ektikleri, geriye kalan tarlaları da nadasa bıraktıkları varsayımında bulunulabilir. Ayrıca Müslüman hanelerin hayvanlarını otlatabilecekleri çayır arazisinin de grafikte görüldüğü üzere \%3 ile sınırlı kaldığını belirtmek gerekir.

Vize merkezi temettuât defterlerinde, ekilmemiş tarlalar hariç olmak üzere mahallelerin üç çeşit araziden elde ettikleri kazançlar bulunmaktadır. Bu kazançlar 1845 yılına aittir. Aşağıdaki tabloda mahallelerin arazilerinden sağladıkları gelirler gösterilmiştir.

Tablo 5: Müslüman Mahallelerin Tarım Arazilerinden Elde Ettikleri Kazançlar (Kuruş Cinsinden)

\begin{tabular}{lcccc}
\hline \multirow{2}{*}{$\begin{array}{c}\text { Mahalle Adı } \\
\text { (Hane Sayısı) }\end{array}$} & \multicolumn{2}{c}{$\begin{array}{c}\text { Mahallelerin Arazilerden Elde Ettikleri } \\
\text { Kazançlar }\end{array}$} & \multirow{2}{*}{ Toplam: } \\
\cline { 2 - 4 } & $\begin{array}{c}\text { Mezrû (Ekilmiş) } \\
\text { Tarla }\end{array}$ & $\begin{array}{c}\text { Bağ- } \\
\text { Bahçe }\end{array}$ & Çayır & \\
\hline Derûn-ı Kal'a (90) & 23.364 & 3.070 & 656 & \\
\hline Seyyid Kasım (51) & 31.070 & 1.827 & 1.537 & 34.089 \\
\hline Hacı Şâzi (37) & 34.177 & 1.143 & 30 & 35.350 \\
\hline Yenice Müsellem (14) & 8.028 & 484 & 333 & 8.845 \\
\hline Manavlar (26) & 11.574 & 482 & 295 & 12.350 \\
\hline Toplam: & 108.212 & 7.005 & 2.851 & 118.067 \\
\hline
\end{tabular}

Tabloda mahallelerin üç arazi çeşidinden elde ettikleri kazançlar toplamına bakıldığında, 35.350 kuruş ile en yüksek geliri Hacı Şâzi Mahallesi elde etmiştir. En düşük kazanç sağlayan mahalle ise, 8.845 kuruş ile Yenice Müsellem Mahallesidir. 


\subsection{Mahallelerde Bulunan Hayvan Miktarları}

Mahallelerde bulunan türlerine göre hayvan sayıları yüzdelik oranlarıyla birlikte aşağıdaki tabloda gösterilmektedir.

Tablo 6: Vize Kazasındaki Müslüman Mahallelerdeki Hayvan Sayıları ve Yüzdelik Oranları

\begin{tabular}{lcccccc}
\hline \multicolumn{1}{c}{ Mahalle Adı } & \multicolumn{5}{c}{ Hayvan Sayıları } \\
\cline { 2 - 7 } & \multicolumn{2}{c}{$\begin{array}{c}\text { Büyükbaş } \\
\text { Hayvanlar }\end{array}$} & \multicolumn{2}{c}{ Küükbaş Hayvanlar } & Yük ve Binek Hayvanları \\
\cline { 2 - 7 } & Adet & $\begin{array}{c}\text { Yüzde } \\
\text { Oranı }\end{array}$ & Adet & Yüzde Oranı & Adet & Yüzde Oranı \\
\hline Derûn-ı Kal'a & 112 & $19,68 \%$ & 249 & $68,98 \%$ & 48 & $34,04 \%$ \\
\hline Seyyid Kasım & 194 & $34,09 \%$ & 0 & $0,00 \%$ & 54 & $38,30 \%$ \\
\hline Hacı Şâzi & 127 & $22,32 \%$ & 0 & $0,00 \%$ & 12 & $8,51 \%$ \\
\hline Yenice Müsellem & 58 & $10,19 \%$ & 37 & $10,25 \%$ & 10 & $7,09 \%$ \\
\hline Manavlar & 78 & $13,71 \%$ & 75 & $20,78 \%$ & 17 & $12,06 \%$ \\
\hline Toplam & 569 & $100,00 \%$ & 361 & $100,00 \%$ & 141 & $100,00 \%$ \\
\hline
\end{tabular}

Defterlerde büyükbaş olarak, inek ve manda cinsi hayvanlar kaydedilmiştir. Tablo incelendiğinde, 194 adetle en çok büyükbaş hayvanı bulunan mahallenin Seyyid Kasım Mahallesi olduğu gözüküyor. Daha öncede belirtildiği üzere bu mahallenin en fazla çayıra sahip olması büyükbaş hayvan beslemeye elverişli bir ortam sağlamış olmalıdır. Ayrıca en az hayvan sayısına sahip mahalle ise 58 adet ile Yenice Müsellem Mahallesidir.

Küçükbaş hayvan olarak defterde, sadece koyun cinsi kaydedildiği anlaşılmaktadır. Yine tablo incelendiğinde Seyyid Kasım ve Hacı Şâzi Mahallesinde küçükbaş hayvan mevcut değildir. Ayrıca defterlerde diğer mahallelere ait küçükbaş miktarı 1-2 hanede belirtilmiştir.

Son olarak, yük ve binek hayvanlarına dair kayıtlar da bulunmaktadır. Bu türden hayvanlar, “merkep (eşek)" ve "bargir (beygir)" olarak defterlerde kaydedilmiştir. Bütün mahallelerde bulunan bu türden hayvanlar, hanelerin yük taşıma ve ulaşım gibi ihtiyaçlarını karşılamaktadır. XIX. yüzyı1 şartları göz önüne alındığında bu türden hayvanların ne denli önemli bir yere sahip olduğunu tahmin etmek hiç zor değildir.

\subsection{Mahallelerdeki Hanelerin Senelik Kazançları ve Vergi Miktarları}

Aşağıdaki tabloda 5 mahalleye ait toplam kazanç, ödenen vergi, hanelerin net kazancı ve hane başına düşen net kazanç-vergiler gösterilmektedir.

Tablo 7: Müslüman Mahallelerdeki Hanelerin Toplam Kazançları ve Ödedikleri Vergi Miktarları

\begin{tabular}{|c|c|c|c|c|c|}
\hline \multirow[t]{2}{*}{ Mahalle Adı } & \multirow{2}{*}{$\begin{array}{l}\text { Toplam } \\
\text { Kazanç }\end{array}$} & \multirow{2}{*}{$\begin{array}{c}\text { Ödenen } \\
\text { Toplam } \\
\text { Vergi }\end{array}$} & \multirow{2}{*}{$\begin{array}{l}\text { Hane } \\
\text { Sayısı }\end{array}$} & \multicolumn{2}{|c|}{ Hane Başına Düşen } \\
\hline & & & & Net Kazanç & Vergi \\
\hline Derûn-ı Kal'a & 121.660 & 7.033 & 90 & 1.274 & 78 \\
\hline Seyyid Kasım & 52.003 & 2.281 & 51 & 975 & 45 \\
\hline Hacı Şâzi & 41.931 & 1.492 & 37 & 1.093 & 40 \\
\hline Yenice Müsellem & 12.249 & 1.880 & 14 & 741 & 134 \\
\hline Manavlar & 19.660 & 1.245 & 26 & 708 & 48 \\
\hline Toplam & 247.503 & 13.931 & 218 & 4.790 & 345 \\
\hline
\end{tabular}


Tablo incelendiğinde en çok hane sayısına sahip olan Derûn-1 Kal'a Mahallesi'nin en çok kazanca ve vergi miktarına sahip olduğu görülmektedir. Ayrıca belirtilmelidir ki, bu miktarın fazla olmasının nedeni Ferhat Bey'in sahip olduğu çiftliklerden sağladığ 46 bin 727 kuruş senelik kazançtır. Derun-1 Kal'a Mahallesini takiben hane sayısı azaldıkça kazancın da vergi miktarının da azaldığı ortaya çıkmaktadır. Daha önce de belirtildiği üzere Tanzimat'ın herkesin kazancına göre vergi ödeme prensibinin örneği burada görülmektedir.

\section{Gayrimüslim Mahallelerin Sosyo-Ekonomik Durumu}

\subsection{Hane Reislerinin Tahlili}

Gayrimüslim hanelerin kayıtlı olduğu temettuât defterlerinde, tıpkı Müslüman hanelerde olduğu gibi, hane reislerinin isimleri baba isimleriyle birlikte kaydedilmiştir. Örneğin, 1 numaralı hane reisinin, "Kiryan oğlu Dimitri" şeklinde kaydedildiği görülmektedir (BOA, ML.VRD.TMT, d. 06553, vr. 2, hn. 1). Bu kayıtların yanında bazı hane reislerinin de baba adları olmadan mesleklerine, nâm ve şöhretlerine göre lakaplarla kaydedildiği görülüyor. Yine birkaç örnek vermek gerekirse, Yazı Mahallesi'nde yaşayan Çoban Kiryan (BOA, d. 06553, vr. 7, hn. 24), Kürkçü Yani (BOA, d. 06553, vr. 19, hn. 84), Hacı Mosko (BOA, d. 06553, vr. 18, hn. 76), Nakkaş Kosta (BOA, d. 06553, vr. 22, hn. 97) ve Bulaca Mahallesi'nde yaşayan Dağcı Yemandi (BOA, d. 06553, vr. 31, hn. 144), Ayanalı Manol (BOA, d. 06553, vr. 29, hn. 133). Burada, Ayanalı Manol'un Vize'nin bir köyü olan Ayana $^{5}$ dan merkez mahalleye yerleştiği anlaşılmaktadır.

Diğer taraftan, gayrimüslim hanelerin kayıtlı olduğu temettuât defterinde dikkat çeken bir husus da, bazı hane reislerinin isimlerinin baş tarafına defteri tutan memur tarafindan, Arapça olarak, $\varepsilon$ ('Ayn) ve b (T1) harflerinin konularak kaydedilmesidir. Bu şekildeki kayıtlara yalnızca 76 hanesi bulunan Yazı Mahallesi'nde rastlanmaktadır. 'Ayn harfiyle kaydedilmiş 4 hane bulunmakla birlikte, T1 harfiyle kaydedilmiş olan hane sayısı ise toplamda 72'dir (BOA, d. 06553, vr. 31-44). Bu harfler gayrimüslimlerin ödeyecekleri cizye vergisinin belirlenmesinde yardımcı olmaktadır. Nitekim cizye vergisi kişinin ekonomik gücüne göre â'la (yüksek), evsat (orta), edna (düşük) olmak üzere üç sınıfa ayrılmakta idi. Mükellefler gelirleri itibariyle zengin, orta halli ve fakir olmalarına göre bu sınıflardan birine dâhil olarak bu vergiyi ödemekle mükellef idiler (Çavdar, 2014: 467). Belgeden anlaşıldığına göre, Yazı Mahallesi’nin büyük çoğunluğu orta halli gelir sahibi kimselerdir.

Sonuç olarak, hane reislerinin kayıtları, Müslüman hane reisleriyle benzer özellikler taşımaktadır. Şahısların baba isimleriyle birlikte kaydedilmeleri ve kişilerin meşgul oldukları mesleklerin unvanlarıyla birlikte kaydedilmesi buna örnek olarak verilebilir. Buradaki tek farklılığın, Müslüman mahallelere ait temettuâtlardaki mevcut kadın isimleri, hanelerin kayıtlarında bulunmamasidır.

\subsection{Hane Reislerinin Meslekleri ve Kazançları}

Gayrimüslimlere ait temettuât defterlerinde toplam 21 türde farklı meslek gruplarının olduğu tespit edilmiştir. Aşağıdaki tabloda bu mesleklere ait bilgiler bulunmaktadır.

\footnotetext{
5 Ayana Köyü'nün temettuât defteri hakkında bk: (BOA, ML.VRD.TMT, d.06557). Osmanlı Arşivindeki kataloglarda Ayan köyü olarak kaydedilmiştir. Köyün adının, XVI. yüzyıldaki Ayo-yani köyünün adından gelmiş olabileceği düşünülmektedir (Sakin, 167). Öte yandan Ayana Köyü, 1514-1550 yılları arasındaki arşiv kayıtlarında idarî olarak Aydos Kazası sınırları içerisinde Silistre'ye bağlı bir köy olarak geçmektedir (Ünal vd., 2013: 90). Günümüzde ise, Kırklareli'ye bağlı Vize ilçe sınırları içerisinde, şimdiki adı Küçükyayla Köyüdür (Dâhiliye Vekâleti Mahallî İdareler Umum Müdürlüğü, 1933: 516).
} 
Tablo 8: Gayrimüslim Mahallelerdeki Hane Reislerinin Meslekleri ve Gelirleri

\begin{tabular}{|c|c|c|c|c|}
\hline \multirow{2}{*}{$\begin{array}{l}\stackrel{0}{z} \\
\stackrel{n}{n}\end{array}$} & \multirow[t]{2}{*}{ Meslek Adı } & \multicolumn{2}{|c|}{ Kuruş Cinsinden } & \multirow[t]{2}{*}{ Hane Reisi Sayısı } \\
\hline & & $\begin{array}{c}\text { En Düşük } \\
\text { Kazanç }\end{array}$ & $\begin{array}{c}\text { En Yüksek } \\
\text { Kazanç }\end{array}$ & \\
\hline 1 & Çiftçi & 101 & 4.704 & 74 \\
\hline 2 & Çoban (Buzağı-Sığır) & 80 & 1.177 & 5 \\
\hline 3 & Nalbant & 500 & 800 & 2 \\
\hline 4 & Bâzergân (Tüccar) & 250 & 700 & 6 \\
\hline 5 & Boyac1 & 250 & 700 & 4 \\
\hline 6 & Kürkçü & 300 & 550 & 2 \\
\hline 7 & Dülger & 15 & 500 & 28 \\
\hline 8 & Bakkal & 108 & 500 & 3 \\
\hline 9 & Terzi & 50 & 500 & 11 \\
\hline 10 & Arabacı & 150 & 500 & 5 \\
\hline 11 & Dağc1 & 50 & 500 & 12 \\
\hline 12 & Rençber & --- & 382 & 1 \\
\hline 13 & Koçucu (Koşucu) & 100 & 350 & 3 \\
\hline 14 & Hizmetkâr & 100 & 320 & 14 \\
\hline 15 & Kirac1 & 100 & 320 & 3 \\
\hline 16 & Yevmiyeci & 100 & 300 & 7 \\
\hline 17 & Papaz & 300 & 300 & 2 \\
\hline 18 & Nakkaş & --- & 250 & 1 \\
\hline 19 & Değirmenci & 150 & 200 & 2 \\
\hline 20 & Yemenici & --- & 200 & 1 \\
\hline 21 & Abacı & --- & 120 & 1 \\
\hline \multicolumn{2}{|c|}{ Toplam } & 2.704 & 13.873 & 187 \\
\hline
\end{tabular}

Tabloya bakıldığında, gayrimüslim mahallelerde en çok rağbet olunan meslek çiftçiliktir. Ayrıca en fazla tercih edilen ikinci bir meslek kolu da günümüzde ağaç işçiliği ya da marangozluk olarak adlandırılan dülgerliktir. Buradan da gayrimüslim haneler için ormancılığın önemli bir gelir kaynağı olduğunu söylemek mümkündür.

Öte yandan temettuât defterinde "koçuculuk" (koşuculuk) olarak kaydedilmiş bir meslek dikkat çekmektedir. Günümüzde ismi pek bilinmeyen bu mesleği icra eden koçucu, o dönemde hububat taşımaya yarayan arabayı kullanan kişilere verilen bir isimdi (Sami, 1091).

Hane reislerinin geçimlerini sürdürdükleri bu mesleklerden elde ettikleri senelik en yüksek kazançları ise şu şekildedir: "Bir çiftçi 4.704 kuruş kazanç elde ederken, çoban 1.177 kuruş, nalbant 800 kuruş, tüccar ve boyac1 700 kuruş, kürkçü 550 kuruş, dülger, bakkal, terzi, arabacı ve dağc1 500 kuruş kazanç elde etmektedir. Ayrıca bir rençberin en yüksek kazancı 382 kuruş, koşucunun 350 kuruş, hizmetkârın 320 kuruş, yevmiyeci ve papazın 300 kuruş, nakkaşın 250 kuruş, değirmenci ve yemenicinin ise senelik en yüksek kazanc1 200 kuruştur. Meslekler arasında en düşük gelir elde eden abacının da senelik en yüksek kazancı 120 kuruştur.

\subsection{Mahallelerdeki Tarım Arazileri ve Hanelerin Kazançları}

Gayrimüslim hanelerin kaydedildiği temettuât defterinde tespit edilen üç mahallede (Karş1, Bulaca ve Yazı) dört farklı türde arazi çeşidi tespit edilmiştir. Bu arazilerin mahallelere göre dağılımı dönüm bazında aşağıdaki grafikte gösterilmektedir. 
Tablo 9: Gayrimüslim Mahallelerdeki Tarım Arazilerinin Miktarları (Dönüm)

\begin{tabular}{|c|c|c|c|c|c|c|c|c|}
\hline \multirow[t]{2}{*}{$\begin{array}{r}\text { Mahalle Adı } \\
\text { (Hane Sayısı) }\end{array}$} & \multicolumn{4}{|c|}{$\begin{array}{c}\text { Mahallelerdeki Arazilerin Çeşitlerine Göre } \\
\text { Toplamı }\end{array}$} & \multicolumn{4}{|c|}{$\begin{array}{c}\text { Hane Başına Düşen Ortalama Arazi } \\
\text { Miktarı }\end{array}$} \\
\hline & $\begin{array}{c}\text { Mezrû } \\
\text { (Ekilmiş) } \\
\text { Tarla }\end{array}$ & $\begin{array}{c}\text { Gayrı Mezrû } \\
\text { (Ekilmemiş) } \\
\text { Tarla }\end{array}$ & Çayır & $\begin{array}{l}\text { Bağ- } \\
\text { Bahçe }\end{array}$ & $\begin{array}{c}\text { Mezrû } \\
\text { (Ekilmiş) } \\
\text { Tarla }\end{array}$ & $\begin{array}{c}\text { Gayrı Mezrû } \\
\text { (Ekilmemiş) } \\
\text { Tarla }\end{array}$ & Çayır & $\begin{array}{l}\text { Bağ- } \\
\text { Bahçe }\end{array}$ \\
\hline Karşı (43) & 274 & 227 & 11 & 19,25 & 6,37 & 5,28 & 0,26 & 0,45 \\
\hline Bulaca (98) & 944,5 & 812 & 0 & 90,5 & 9,64 & 8,29 & 0,00 & 0,92 \\
\hline Yazı (76) & 231,5 & 170 & 6 & 52,5 & 3,05 & 2,24 & 0,08 & 0,69 \\
\hline Toplam: & 1450 & 1209 & 17 & 162,25 & 19,06 & 15,80 & 0,33 & 2,06 \\
\hline
\end{tabular}

Tablo 9 incelendiğinde, en çok ekilmiş tarlaya sahip olan mahalle, 98 hanenin meskûn bulunduğu Bulaca Mahallesidir. 944,5 dönüm ekili tarlası olan ve hiç çayır arazisi bulunmayan bu mahallede ekilmemiş tarla ve bağ-bahçe arazilerinin yine diğer mahallelere oranla daha fazla olduğu görülmektedir. Bu mahalleyi takiben 43 haneli Karşı Mahallesine ait 274 dönüm ekilmiş tarla bulunmakla beraber, 76 haneye sahip Yazı Mahallesinde ise 231,5 dönüm ekilmiş tarla bulunmaktadır. Bu mahallelerin arazi türlerinin dağılım oranları aşağıdaki grafikte gösterilmiştir.

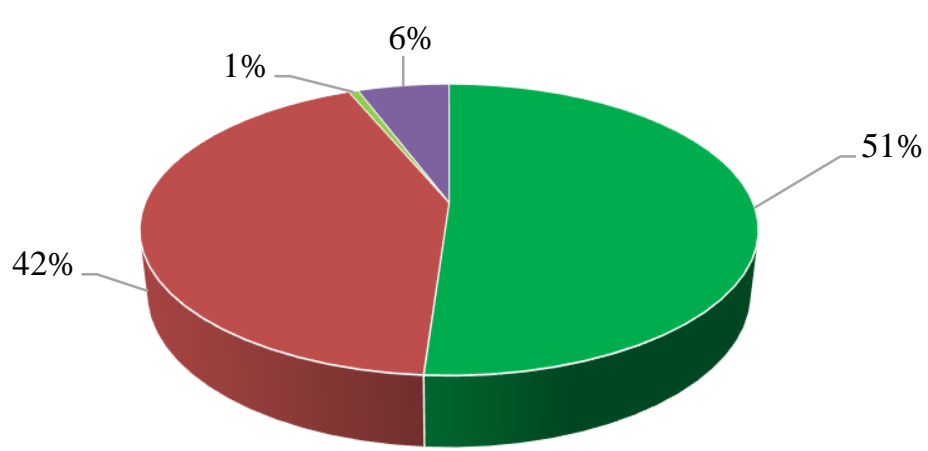

- Mezrû (Ekilmiş) Tarla " Gayrı Mezrû (Ekilmemiş) Tarla "Çayır " Bağ-Bahçe

Grafik 2: Gayrimüslim Mahallelerin Sahip Oldukları Tarım Arazilerin Yüzdelik Oranları

Grafik 2 incelendiğinde, gayrimüslim mahallelerdeki arazilerin \%93'lük kısmını oluşturan tarlaların \%51'i ekili haldedir. Geriye kalan \%42'lik kısmı ise ekilmemiş, yani gayrı mezrûdur. Bu rakamlardan arazilerin yarısının ekili olduğu anlaşılmaktadır. Böyle olmasına rağmen, hanelerin ekili tarlalardan kendi ihtiyaçlarını karşılayacak düzeyde bir verim elde ettiklerini söylemek mümkündür. Müslüman mahallelerin arazilerinde olduğu gibi benzer şekilde bağ arazisi, gayrimüslim mahallelerde de \%6'lık bir oranla yer almaktadır. Dolayısıyla üzüm yetiştiriciliği önemli tarımsal bir faaliyet olarak burada da ortaya çıkmaktadır. Son olarak çayır arazisi de \%1'lik bir oranla sınırlı kalmaktadır.

Gayrimüslim mahallelerin 1845 yılında tarım arazilerinden elde ettikleri kazançlar aşağıdaki tabloda gösterilmektedir. 
Tablo 10: Gayrimüslim Mahallelerin Tarım Arazilerinden Elde Ettikleri Kazançlar (Kuruş Cinsinden)

\begin{tabular}{lcccc}
\hline \multirow{2}{*}{$\begin{array}{c}\text { Mahalle Adı } \\
\text { (Hane Sayısı) }\end{array}$} & \multicolumn{3}{c}{$\begin{array}{c}\text { Mahallelerin Arazilerden Elde Ettikleri } \\
\text { Kazançlar }\end{array}$} & \multirow{2}{*}{ Toplam: } \\
\cline { 2 - 4 } & $\begin{array}{c}\text { Mezrû (Ekilmiş) } \\
\text { Tarla }\end{array}$ & $\begin{array}{c}\text { Bağ-Bahçe } \\
\text { Karşı (43) }\end{array}$ & \multicolumn{1}{c}{ Çayır } & \\
\hline Bulaca (98) & 21.858 & 1.103 & 285 & 23.246 \\
\hline Yazı (76) & 78.642 & 3.276 & - & 81.918 \\
\hline Toplam: & 19.584 & 1.718 & 105 & 21.407 \\
\hline
\end{tabular}

Tabloda mahallelerin arazilerinden sağladıkları kazançlar toplamına bakıldığında en yüksek gelir sağlayan mahallenin 81.918 kuruş ile Bulaca olduğu açıkça görülmektedir. En az kazancı ise 21.407 kuruş ile Yazı Mahallesi sağlamıştır.

\subsection{Mahallelerde Bulunan Hayvan Miktarları}

Gayrimüslimlere ait temettuât defterinde büyükbaş, küçükbaş, yük ve binek hayvanlarının mahallelere göre miktarları ve oranları aşağıdaki tabloda gösterilmiştir.

Tablo 11: Vize Kazasındaki Gayrimüslim Mahallelerdeki Hayvan Sayıları ve Yüzdelik Oranları

\begin{tabular}{lcccccc}
\hline \multirow{2}{*}{$\begin{array}{c}\text { Mahalle } \\
\text { Adı }\end{array}$} & \multicolumn{5}{c}{ Hayvan Sayıları } \\
\cline { 2 - 7 } & \multicolumn{2}{c}{ Büyükbaş Hayvanlar } & \multicolumn{2}{c}{ Küçükbaş Hayvanlar } & \multicolumn{2}{c}{ Yük ve Binek Hayvanları } \\
\cline { 2 - 7 } & Adet & Yüzde Oranı & Adet & Yüzde Oranı & Adet & Yüzde Oranı \\
\hline Karşı & 164 & $21,00 \%$ & 120 & $15,77 \%$ & 9 & $10,71 \%$ \\
\hline Bulaca & 388 & $49,68 \%$ & 486 & $63,86 \%$ & 48 & $57,14 \%$ \\
\hline Yazı & 229 & $29,32 \%$ & 155 & $20,37 \%$ & 27 & $32,14 \%$ \\
\hline Toplam & 781 & $100,00 \%$ & 761 & $100,00 \%$ & 84 & $100,00 \%$ \\
\hline
\end{tabular}

Temettuât defterinde büyükbaş hayvanlar, "inek" ve "manda" olarak, küçükbaşlar sadece "koyun", yük ve binek hayvanları ise "merkep (eşek)" ve "bârgir (beygir/at)" olarak kaydedilmiştir. Tablo incelendiğinde, en çok hayvan sayısı, dönüm bazında en çok tarım arazisine de sahip olan, Bulaca Mahallesindedir. Bu mahalleyi takiben sırasıyla en çok hayvan miktarı bulunan mahalleler, Yazı Mahallesi ve Karşı Mahalle'dir.

\subsection{Yanya'dan Olup Vize'de Esnaflık Yapan Hanelerin Sosyo-Ekonomik Durumu}

Temettuât defterinde 47 numaralı varakadaki başlıkta, "Yanyalı olup Vize Kazasında gedik suretiyle dükkânları olan esnafin vergi ve temettuât-ı seneviyelerinin miktarı" yazmaktadır. Bakkal olduklar1 yazılan ve hane numaraları belirtilmeyip iki hane olarak kaydedilen bu hane reislerinin, Yanya'dan Vize'ye gelip burada esnaflık yaptıkları anlaşılmaktadır. ${ }^{6}$ Defterin tutulduğu 1845 yılından önce Vize'ye geldikleri anlaşılan bu hane reislerinin Yanya'daki siyasi karışıklıktan dolayı buraya gelmiş oldukları muhtemeldir. ${ }^{7}$

İlk sırada kaydı bulunan Yani oğlu Dakni'nin bakkal esnaflığından bir senelik kazancı 600 kuruş iken, ikinci sırada kaydı bulunan Dimo oğlu Vetro'nun ise bir senelik kazancı 550 kuruştur. Dakni'nin ödediği vergi toplam 130 kuruş iken, Vetro'nun ödediği vergi ise, 120 kuruştur. Toplamda

\footnotetext{
${ }^{6}$ 1820-1822 yılları arasında Tepedelenli Ali Paşa'nın kontrolünde olan Yanya, bu dönemde sancak durumundadır. Defterin kaydedildiği 1845 yılında da muhtemelen sancak hüviyetindedir (Sezen, 801).

${ }^{7}$ Yanya'daki Tepedelenli Ali Paşa'nın isyanı hakkında bk: (Beydilli, 2011).
} 
250 kuruşluk vergi ödeyen bu hane reislerinin yıllık ortalama net kazanc1 425 kuruştur (BOA, d. 06553, vr. 47).

\subsection{Kıptîlerin Sosyo-Ekonomik Durumu}

Defterde "kıptîyân" olarak 3 hane bulunmaktadır. Kıptî, roman taifesine Osmanlı tarafından verilen isimdir. Kıptîler hakkında yapılmış bir çalışmada, geleneksel olarak şu mesleklerle meşgul oldukları yazmaktadır: "Demircilik, nalbantlık, bakırcılık, kalaycılık, sepetçilik, elekçilik, altın arayıcılığı, seyislik, şifacılık, falcılık, ayı oynatıcılığı, akrobatlık, müzisyenlik, çengilik, bohçacılık, oymac1lık, kâhinlik ve dilencilik...” (Tağ, 2015: 18).

Mevcut temettuât defterinde ise kıptî hanelerin tümü demircilik mesleğiyle geçimlerini sağlamaktadır. $\mathrm{Bu}$ noktada, Vize merkezinde yaşayan kıptî hane reislerinin de geleneksel mesleklerini icra ettikleri ortaya çıkmaktadır. Diğer taraftan bu hane reislerinin demircilik mesleğinden elde ettikleri yıllık kazançlar ve ödedikleri vergiler aşağıdaki tabloda gösterilmiştir (BOA, d. 06553, vr. 46)

Tablo 12: Vize Kazasındaki Kıptî Hanelerin Kazançları ve Ödedikleri Vergi Miktarları

\begin{tabular}{|c|c|c|c|c|c|c|}
\hline 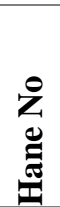 & Hane Reisi & $\begin{array}{c}\text { Demircilik } \\
\text { Mesleğinden } \\
1 \text { Ylllık } \\
\text { Kazanç } \\
\text { (Kuruş) }\end{array}$ & $\begin{array}{l}\text { Diğer } \\
\text { Gelirler } \\
\text { (Kuruş) }\end{array}$ & $\begin{array}{l}\text { Toplam } \\
\text { Kazanç } \\
\text { (Kuruş) }\end{array}$ & $\begin{array}{c}\text { Ödediği Vergi } \\
\text { Miktarı } \\
\text { (Kuruş) }\end{array}$ & $\begin{array}{c}\text { Net } \\
\text { Kazanç } \\
\text { (Kuruş) }\end{array}$ \\
\hline 1 & Asiyostol oğlu Penayot & 45 & 400 & 445 & 58 & 387 \\
\hline 2 & Penayot oğlu Kiryan & 80 & 882 & 962 & 70 & 892 \\
\hline 3 & Botofoz oğlu Dimo & 50 & 717 & 767 & 70 & 697 \\
\hline Top & am: & 175 & 1999 & 2174 & 198 & 1976 \\
\hline \multicolumn{3}{|c|}{ Hane başına düşen yıllık ortalama net kazanç: } & & & & 658,67 \\
\hline
\end{tabular}

Temettuât defterindeki verilere göre düzenlenmiş olan yukarıdaki tabloya göre, en fazla net kazanç sağlayan hane reisinin 2 numaralı hane de yaşayan Penayot oğlu Kiryan olduğu görülmektedir. En az kazanca sahip olan ise 1 numaralı hane reisi Botofoz oğlu Dimo'dur.

\subsection{Mahallelerin Senelik Kazançları ve Vergi Miktarları}

Gayrimüslim mahallelerindeki toplam kazançlar, hane başına düşen net kazanç ve vergiler aşağıdaki tabloda sıralanmıştır.

Tablo 13: Gayrimüslim Mahallelerdeki Hanelerin Toplam Kazançları ve Ödedikleri Vergi Miktarı

\begin{tabular}{llllll}
\hline Mahalle Adı & Toplam Kazanç & $\begin{array}{c}\text { Ödenen } \\
\text { Toplam Vergi }\end{array}$ & Hane Sayısı & \multicolumn{2}{c}{ Hane Başına Düşen } \\
\cline { 5 - 6 } & & 3.074 & 43 & 750 & Vergi \\
\hline Karşı & 35.332 & 9.787 & 98 & 996 & 100 \\
\hline Bulaca & 107.425 & 4.373 & 76 & 469 & 58 \\
\hline Yazı & 39.981 & 198 & 3 & 658 & 66 \\
\hline Kıptîler & 2.172 & 250 & 2 & 450 & 125 \\
\hline Esnaflar & 1.150 & 17.682 & 222 & 3.323 & 420 \\
\hline Toplam & 186.060 & & & & \\
\hline
\end{tabular}

Tabloya göre, gayrimüslim mahallelerde hane başına düşen net kazancın en yüksek olduğu mahallenin "Bulaca" olduğu görülmektedir. Hane sayısının diğer mahallelere göre fazla olduğu görülen Bulaca Mahallesinde hane başına düşen vergi miktarı 100 kuruştur. Hane başına düşen net 
kazancı en az olan 450 kuruş ile esnaflardır. Ayrıca en yüksek miktarda vergi ödeyen esnafların, tabloya göre daha az miktarda kazanç elde ettikleri de dikkate değer bir husustur.

Kıptîler ve esnaflar meslekî olarak değerlendirildiğinde, bakkal işletmenin demircilikten daha kazançlı bir iş olduğu çok net ortadadır.

\section{Temettuât Defterlerine Göre Müslüman ve Gayrimüslim Mahallelerin Değerlendirilmesi}

Temettuât defterlerindeki Müslüman ve gayrimüslim hanelere dair sayısal verileri dört hususta değerlendirmek mümkündür. Bu hususlardan birincisi, mahallelerin yıllık net kazançları ve ödedikleri vergi miktarlarıdır. Aşağıdaki tabloda bu miktarlar kuruş cinsinden gösterilmektedir.

Tablo 14: Müslüman ve Gayrimüslim Mahallelerin Ortalama Yıllık Net Kazancı ve Ödedikleri Vergiler (Kuruş Cinsinden)

\begin{tabular}{lcc}
\hline Mahalleler: & $\begin{array}{c}\text { Hane Başına } \\
\text { Düssen } \\
\text { Ortalama } \\
\text { Yllık Net } \\
\text { Kazanç: }\end{array}$ & $\begin{array}{c}\text { Hane Başına } \\
\text { Düssen Ortalama } \\
\text { Vergi Miktarı: }\end{array}$ \\
\hline Müslüman & 1.071 & 64 \\
\hline Gayrimüslim & 758 & 80 \\
\hline Fark & 313 & 16 \\
\hline Yüzdelik Fark & $\% 29,21$ & $\% 19,77$ \\
\hline
\end{tabular}

Tablodan hareketle şunlar söylenebilir: "Vize Kazasında Müslüman mahallelerdeki hane başına düşen ortalama y1llık net kazanç 1.071 kuruş iken, gayrimüslimlerde bu rakam 758 kuruştur. Burada Müslüman hanelerin, gayrimüslimlerden \%29,21'lik farkla daha çok kazanç sağladığı görülmektedir. Hane başına düşen ortalama vergi miktarı Müslüman mahallelerde 64 kuruş, gayrimüslim mahallelerde ise 80 kuruştur. Yine yüzdelik farkın da 19,77 olduğu ortaya çıkmaktadır. Netice itibarıyla burada en çok kazanç sağlayan Müslüman mahallelerindeki haneler, daha az kazanç sağlayan gayrimüslim hanelere göre 16 kuruş daha az vergi ödemişlerdir. $\mathrm{Bu}$ da muhtemelen gayrimüslimlerin cizye yükümlülüklerinden kaynaklanmaktadır.

İkinci husus, hanelerin yetiştirdiği mahsullerden alınan aşar vergisinin tespiti konusudur. Tahriri gerçekleştiren memurlar, bütün hanelerin yetiştirdiği ürünlerin cinsine ve miktarına göre birim vergi fiyatı belirleyerek deftere kaydetmiştir. Aşağıdaki tablo bunu daha somut bir şekilde açıklamaktadır: 
Tablo 15: Vize Kazasındaki Müslüman ve Gayrimüslim Hanelerin Ürünlerinden Alınan Aşar Vergilerinin Birim Miktarları

\begin{tabular}{lcclcc}
\hline \multicolumn{2}{c}{ MÜSLÜMAN HANELERDE } & \multicolumn{2}{c}{ GAYRIMMÜSLIM HANELERDE } \\
\hline $\begin{array}{l}\text { Tahı̈ } \\
\text { Ürünü: }\end{array}$ & Ölçü: & $\begin{array}{c}\text { Aşar } \\
\text { Vergisi } \\
\text { Miktarı } \\
\text { (Kuruş) }\end{array}$ & $\begin{array}{l}\text { Tahıl } \\
\text { Ürünü: }\end{array}$ & Ölçü: & $\begin{array}{c}\text { Aşar } \\
\text { Vergisi } \\
\text { Miktarı } \\
\text { (Kuruş) }\end{array}$ \\
\hline Buğday & 1 kile & 14 & Buğday & 1 kile & 14 \\
\hline Arpa & 1 kile & 5 & Arpa & 1 kile & 5 \\
\hline $\begin{array}{l}\text { Hayvan } \\
\text { Yemi }\end{array}$ & 1 kile & 4 & Hayvan & 1 kile & 4 \\
\hline Keten & --- & --- & Keten & 1 kile & 16 \\
\hline Çavdar & 1 kile & 6 & Çavdar & 1 kile & 6 \\
\hline Mısır & 1 kile & 8 & Mısır & 1 kile & 8 \\
\hline Fasulye & --- & --- & Fasulye & 1 kile & 1 \\
\hline Nohut & --- & --- & Nohut & 1 kile & 3 \\
\hline Burçak & --- & --- & Burçak & 1 kile & 8 \\
\hline Üzüm & 1 kiyye & 5 & Üzüm & 1 kiyye & 5 \\
\hline
\end{tabular}

Temettuât defterlerinde mahsuller kile ${ }^{8}$ ve kıyye ${ }^{9}$ ölçü birimleriyle kaydedilmiştir. Tablodan da anlaşılacağı üzere, hububat ürünlerinde ölçü birimi olarak kile kullanılmıştır. Kıyye ise sadece üzümde kullanılmıştır. Yani yaklaşık 25 kilogramlık bir buğdaydan 14 kuruş vergi belirlenmiştir. Bununla birlikte 1,282 kilo üzümden de 5 kuruşluk bir vergi alınmıştır. Tablonun tümü değerlendirildiğinde ise gerek Müslüman hanelerde gerekse gayrimüslim hanelerde aynı miktarda vergi alındığı görülmektedir. Ayrıca ürün miktarı az olan keten, fasulye, nohut ve burçak gibi mahsulleri sadece gayrimüslim mahalleler yetiştirmektedir.

\footnotetext{
${ }^{8}$ Kile, hububat ölçeği olarak kullanılan bir tabirdir. Muhtelif çeşitleri olan kilenin en yaygın kullanılan çeşidi İstanbul kilesidir. Bir İstanbul kilesi, zahirenin cinsine göre ortalama 25 kilogram hacmindedir (Pakalın, 281; Kallek, 2002).

${ }^{9}$ Kıyye ya da okka, her şehir ve kasabada farklılık gösteren bir ağırlık ölçü birimi olmakla beraber, en tanınmış olanı her biri 400 dirheme eşit olan 1,282 kilogram olan bir tartı birimidir (Hinz, 1993: 30; Pakalın, 723, Kallek, 2007).
} 
Üçüncü husus, Müslüman ve gayrimüslim mahallelerde yetiştirilen mahsullerin miktarlarıdır. $\mathrm{Bu}$ hususa dair aşağıdaki grafikte (üzüm hariç) ürün çeşitleri ve miktarları gösterilmiştir.

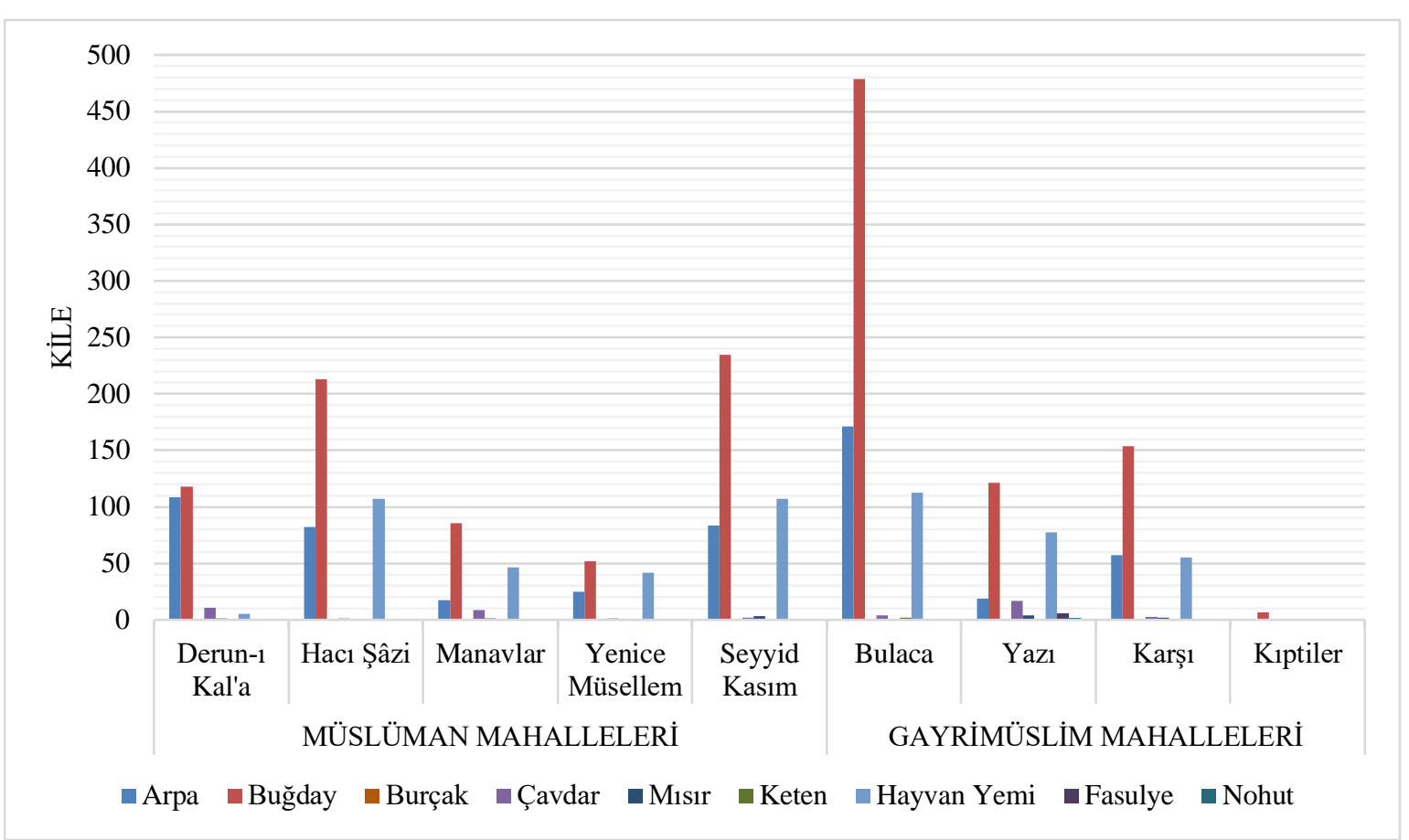

Grafik 3: Vize'de Tüm Mahallelerde Üretilen Mahsullerin Miktarları (Kile Cinsinden)

Grafikte görüleceği üzere Müslüman ve gayrimüslim mahallelerinde üzüm dışında yetişen mamuller, buğday, arpa, çavdar, mısır $^{10}$, burçak, keten, fasulye ve nohut şeklindedir. Bu mamullerin yanında alef, kaplıca ile sehek adı verilen ve hayvan yemi olarak kullanılan ürünler, grafikte genel adla "hayvan yemi" olarak belirtilmiştir. Vize'nin merkez mahallelerinden elde edilen verilere göre en fazla ekimi yapılan ürün buğdaydır. Bunu sırasıyla arpa ve çavdar takip etmektedir. Buğday, arpa ve çavdar dışında sadece gayrimüslim mahallelerinde yetiştirilen keten, fasulye, nohut ve burçak gibi ürünlerin miktarları da oldukça azdır.

Müslüman ve gayrimüslim mahallelerin ürettikleri mahsullerin toplam miktarlarına dair rakamlar ise şöyledir:

- Müslüman mahallelerinde üretilen toplam buğday miktarı $703 \mathrm{kile}=17.575 \mathrm{~kg}$, arpa 316,5 kile $=7.279,5 \mathrm{~kg}$, çavdar $24 \mathrm{kile}=600 \mathrm{~kg}$, misır 6 kile $=150 \mathrm{~kg}$ ve hayvan yemi miktarı ise 307,5 kile $=7.687,5 \mathrm{~kg}$ 'dır.

- Gayrimüslim mahallelerinde ise toplam buğday miktarı $761 \mathrm{kile}=19.025 \mathrm{~kg}$, arpa 247,5 kile $=5.692,5 \mathrm{~kg}$, çavdar $23 \mathrm{kile}=575 \mathrm{~kg}$, misır 6 kile $=150 \mathrm{~kg}$, burçak $0,5 \mathrm{kile}=12,5 \mathrm{~kg}$, keten $2,5 \mathrm{kile}=62,5 \mathrm{~kg}$, hayvan yemi $245,5 \mathrm{kile}=6.137,5 \mathrm{~kg}$, fasulye $5 \mathrm{kile}=125 \mathrm{~kg}$ ve nohut 1 kile $=25 \mathrm{~kg}$ 'dir.

Üzüm yetiştiriciliği, bilindiği üzere hububat üretiminin yanında önemli ve katma değeri yüksek bir tarımsal faaliyettir. Üzümle ilgili olarak, temettuât defterlerinde mahsullerin miktarı kıyye üzerinden belirlenmiştir. Müslüman mahallelerindeki toplam üzüm miktarı 2731 kıyye $=3501 \mathrm{~kg}$

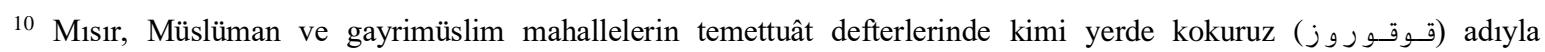
kaydedilmiştir. Kokuruz kelimesi sözlükte Rumca kökenli bir kelime olup, koçanıyla beraber mısıra verilmiş isimdir (Sami, 1105). 
etmektedir. Aynı şekilde gayrimüslim mahallelerdeki toplam üzüm miktarı ise 4252 kıyye $=5451$ kg'dır. Bu rakamların genel toplamına bakıldığında, Vize'de $36.600 \mathrm{~kg}$ buğday, $12.972 \mathrm{~kg}$ arpa, $1.175 \mathrm{~kg}$ çavdar, $13.825 \mathrm{~kg}$ hayvan yemi, $300 \mathrm{~kg}$ mısır, $12,5 \mathrm{~kg}$ keten ve $8.952 \mathrm{~kg}$ üzüm üretilmiştir.

Dördüncü husus ise, hayvanlardan elde edilen kazançlardır. Hayvanların cinsine göre bir birim fiyat belirlenerek, hayvan miktarı üzerinden bir hesaplama yapılmıştır. Bu fiyatlar, hayvanların cinsine göre aşağıdaki tabloda gösterilmiştir.

Tablo 16: Müslüman ve Gayrimüslim Hanelerin Hayvanlardan Elde Ettikleri Kazançların Birim Fiyatlar1

\begin{tabular}{cll}
\hline & Hayvan Cinsi: & $\begin{array}{l}\text { Birim } \\
\text { Fiyat } \\
\text { (Kuruş): }\end{array}$ \\
\hline Büyükbaş & Sütü Sağılabilen (Sağmal) İnek & 15 \\
\cline { 2 - 3 } Hayvanlar & Manda & 30 \\
\hline Küçükbaş & Sütü Sağıllabilen (Sağmal) Koyun & 6 \\
\cline { 2 - 3 } Hayvanlar & Kısır Koyun & 2 \\
\hline
\end{tabular}

Tablo incelendiğinde, büyükbaş hayvanlarda, sütü sağılabilen (sağmal) inekler 15 kuruş, manda cinsinde ise 30 kuruş bir fiyat belirlenmiștir. Küçükbaș hayvanlarda sütü sağılabilen (sağmal) koyun cinsinde 6 kuruş, kısır koyunlarda ise 2 kuruş birim fiyat üzerinden hanelerin kazançları hesaplanmıştır. Burada hanelerin, hayvanlardan en yüksek düzeyde elde edecekleri verim üzerinden bir değerlendirme yapıldığını söylemek mümkündür.

\section{Sonuç}

Tanzimat'ın ilanıyla birlikte başlayan süreçte, halktan adaletli bir vergi toplama sistemi getirmeye çalışan Osmanlı Devleti, çeşitli eyaletlerinde temettuât sayımlarını gerçekleştirmiştir. 1840 yılında muhassıllık teşkilatının uhdesinde gerçekleştirilen sayımlardan bir sonuç elde edilememiştir. Buradaki problem, merkezden gönderilen muhassılların vergileri adil ölçülerde belirleyememelerinden kaynaklanmaktadır. Daha sonra yerel idareciler ve din görevlileri vasıtasıyla bu sorunun önemli ölçüde aşıldığı anlaşılmaktadır.

Bu çalışmada Rumeli bölgesindeki Vize Kazası merkez mahallelerin temettuât kayıtları incelenmiştir. Bu kayıtlar ışığında, Müslüman ve gayrimüslim mahalleler tespit edilip, iki farklı dine mensup topluluğun XIX. yüzyıl ortalarında sosyal ve ekonomik durumları ortaya konulmaya çalışılmıştır.

Bilindiği üzere, Osmanlı Devleti'nin ekonomik temeli tarım ve hayvancılıktır. Küçük bir Trakya kasabası olan Vize'de de durum benzer şekildedir. Nitekim Vize temettuât defterlerindeki hanelerin büyük çoğunluğunun, çiftçilik ile geçimlerini sağlamaları bunu doğrulamaktadır.

İlçenin demografik yapısına bakıldığında, Vize'de merkez mahallelerin tahmini olarak hesap edilebilen ortalama Müslüman ve gayrimüslim nüfus oranı neredeyse yarı yarıyadır.

Bundan başka, Vize temettuât defterlerindeki meslek kayıtlarından anlaşıldığına göre, çiftçiliğin yanında Müslüman hane reisleri, en çok debbağlık (dericilik) yapmaktaydı. Gayrimüslim hane reisleri ise en çok dülgerlik (ağaç işleri) işiyle uğraşmaktaydı. Bu sebeple, Vize halkının tarım ve hayvancılığa ilaveten bu tür zanaat kollarını da tercih ettiğini belirtmek gerekir. Dolayısıyla hayvancılık ve ormancılığın yan kollarının Vize'de önemli bir gelir kaynağı olduğu ortaya çıkmaktadır.

Öte yandan dikkat çeken önemli bir husus da Vize'deki hanelerin sahip oldukları tarım arazileridir. Müslüman ve gayrimüslim hanelerin sahip oldukları tarım arazilerinin dağılımı 
incelendiğinde, ekilmiş tarlaların oranı Müslüman mahallelerde $\% 49$, gayrimüslimlerde ise, $\% 51$ 'dir. Birbirine yakın bu rakamlara bakıldığında arazilerin neredeyse yarısının ekilmediği anlaşılıyor. Dolayısıyla ekilen kısımlar buradaki ahalinin ihtiyaçlarına kifayet ediyor olmalıdır. Bunun yanında, günümüzde Trakya coğrafyasında yapılmaya devam eden üzüm yetiştiriciliği o dönemde de çok önemli ve katma değeri yüksek bir tarımsal faaliyet olarak öne çıkmaktadır.

Vize'nin merkez mahallelerinin bir diğer gelir kaynağı da hayvancılıktır. Temettuât defterlerindeki rakamsal veriler incelendiğinde, Müslüman mahallelerindeki hanelerin sahip olduğu büyükbaş ve küçükbaş hayvan sayılarının, gayrimüslim hanelerin sahip olduğu hayvan sayılarından daha az olduğu görülmektedir. Bunun nedeni, çiftçilik ile uğraşan gayrimüslim hane reislerinin sayısının Müslüman hane reislerinden fazla olması olabilir. Çiftçi sayısının fazla olması, aynı zamanda çiftçinin sahip olduğu hayvan sayısını da niceliksel olarak arttırmış olmalıdır. Ayrıca, Müslüman mahallelerdeki hanelerin küçükbaştan daha çok büyükbaş hayvan yetiştiriciliği yaptıkları görülmektedir.

\section{Kaynakça}

\section{Arşiv Kaynakları:}

Cumhurbaşkanlığı Devlet Arşivleri Başkanlığı Osmanlı Arşivi (BOA), Maliye Vâridat Muhasebesi Temettuât Defterleri (ML.VRD.TMT):

--- d. 06533,

--- d. 06541,

--- d. 06548.

--- d. 06551,

--- d. 06553,

--- d. 06554,

\section{Kaynak Eser, Yayınlanmış Eser, Araştırma ve İnceleme Eserleri}

Adıyeke, N. (2000). Temettuât Sayımları ve Bu Sayımları Düzenleyen Nizamname Örnekleri. Osmanlı Tarihi Araştırmaları Dergisi, (11), 769-823.

Ayverdi, İ. (2008). Misalli Büyük Türkçe Sözlük. Kubbealtı Neşriyat, C. 3.

Başbakanlık Osmanlı Arşivi Rehberi. (2010). Başbakanlık Basımevi.

Beydilli, K. (2011). Tepedelenli Ali Paşa. Diyanet İslam Ansiklopedisi (DİA), C. 40.

Birken, A. (1976). Die Provinzen des Osmanischen Reiches. Dr. Ludwig Reichert Verlag.

Bizbirlik, A. ve Atar, Z. (2009). XIX. Yüzyıl Osmanlı Tarihinde Temettuat Defterlerinin Yeri: Saruhan Sancağı Mütevelli Çiftliği Temettuat Defteri Örneği. Sakarya Üniversitesi Fen Edebiyat Dergisi, (1), 37-57.

Büyük Larousse Sözlük ve Ansiklopedisi. (1986). Vize. Librairie Larousse, C. 23.

Çadırcı, M. (2013). Tanzimat Döneminde Anadolu Kentlerinin Sosyal ve Ekonomik Yapısı. Türk Tarih Kurumu Yayınları.

Çavdar, N. (2014). XIX. Yüzyıl Ortalarında Tokat’ta Katolik Ermeniler: Demografi-Ekonomi. Yeni Türkiye Dergisi, (60), 449-470. 
Dâhiliye Vekâleti Mahallî İdareler Umum Müdürlüğü. (1933). Köylerimiz. İstanbul Matbaacılık ve Neşriyat Türk Anonim Şirketi.

Devellioğlu, F. (1996). Osmanlıca-Türkçe Ansiklopedik Lûgat. Aydın Kitabevi.

Doğan, F. (2014). Temettuat Defterlerine Göre Tanzimat Döneminde Bir Trakya Kasabası: Pınarhisar. Karadeniz Araştırmaları Dergisi, (41), 208-225.

Efe, A. (2002). Muhassillık Teşkilatı. [Yayımlanmamış doktora tezi]. Anadolu Üniversitesi Sosyal Bilimler Enstitüsü.

Eyice, S. (1991). Ayasofya Camii. DİA, C. 4.

Gökbilgin, M. T. (2007). XV. ve XVI. Asırlarda Edirne ve Paşa Livası. İşaret Yayınları.

Göyünç, N. (1997). Hâne. DİA, C. 15.

Güran, T. (2000). 19. Yüzyıl Temettüat Tahrirleri. Osmanl Devleti'nde Bilgi ve İstatistik. Başbakanlık Devlet İstatistik Enstitüsü Yayınları.

Güran, T. (2019). 19. Yüzyılda Osmanlı Ekonomisi Üzerine Araştırm.alar, Türkiye İş Bankası Kültür Yayınları.

Hinz, W. (1990). İslâm'da Ölçü Sistemleri. (çev.) Acar Sevim, Marmara Üniversitesi Yayınları.

İnalcık, H. (2011). Kuruluş Dönemi (1302-1481) Osmanlı Sultanları. İSAM Yayınları.

İpek, E. (2014). Temettuât Defterlerine Göre Babaeski. [Yayımlanmamış yüksek lisans tezi]. Kırklareli Üniversitesi Sosyal Bilimler Enstitüsü.

Kallek, C. (2002). Kile. DIAA, C. 25.

Kallek, C. (2007). Okka. DİA, C. 33.

Karamursal, Z. (1989). Osmanlı Malî Tarihi Hakkında Tetkikler. Türk Tarih Kurumu Yayınları.

Küçükaşçı, M. S. ve Yel, A. M. (2003). Mahalle. DİA, C. 27.

Kütükoğlu, M. (1995). Osmanlı Sosyal ve İktisadi Tarihi Kaynaklarından Temettü Defterleri. Belleten, LIX (225).

Ortaylı, İ. (2018). Tanzimat Devrinde Osmanlı Mahallì İdareleri (1840-1880). Türk Tarih Kurumu Yayınları.

Öz, M. (2010). Tahrir. DİA, C. 39.

Özkaya, Y. ve Akyıldız, A (2006). Muhassil. DİA, C. 31.

Öztürk, S. (2003). Türkiye'de Temettuat Çalışmaları. Türkiye Araştırmaları Literatür Dergisi, (I), C. I, 287-304.

Pakalın, M. Z. (1993). Osmanlı Tarih Deyimleri ve Terimleri Sözlüğü. Millî Eğitim Bakanlığı Yayınları, C. I-II-III.

Redhouse, J. W. (1890). A Turkish and English Lexicon Shewing in English the Significations of the Turkish Terms.

Rumeli Eyaleti (1514-1550) Yer Adları-I. (2013). (Ed. Uğur Ünal), Başbakanlık Osmanlı Arşivi Yayınları.

Sakin, O. (2008). IV. Vize Tarih ve Kültür Sempozyumu Bildirileri. Vize Kazası Tarihi Kaynaklarindan Temettuat Defterleri. (Ed. Güler Yarc1 ve Hüseyin Salman).

Sami, Ş. (2010). Kâmus-ı Türkî. Çağrı Yayınları. 
Sezen, T. (2017). Osmanlı Yer Adları. Başbakanlık Osmanlı Arşivi Yayın No: 26, Genişletilmiş İkinci Bask1.

Tabakoğlu, A. (2012). Türkiye İktisat Tarihi. Dergâh Yayınları.

Tağ, M. (2015). Temettuât Defterlerine Göre Edirne'de Romanlar. [Yayımlanmamış yüksek lisans tezi]. Trakya Üniversitesi Sosyal Bilimler Enstitüsü.

Yalçın, A. (2004). Temettuat Defterlerine Göre 19. Yüzyıl Ortalarında Silifke Kazasının Sosyal ve Ekonomik Yapısı. Ankara Üniversitesi Osmanlı Tarihi Araştırma ve Uygulama Merkezi Dergisi, (15), 13-87.

Yarc1, G. (2005). II. Vize Tarih ve Kültür Sempozyumu Bildirileri. Arşiv Belgeleri Işı̆̆ııda Vize (XVIII. XX. yy.).

Yurt Ansiklopedisi. (1983). Vize. Anadolu Yayıncılık, C. 7. 


\section{Ekler}

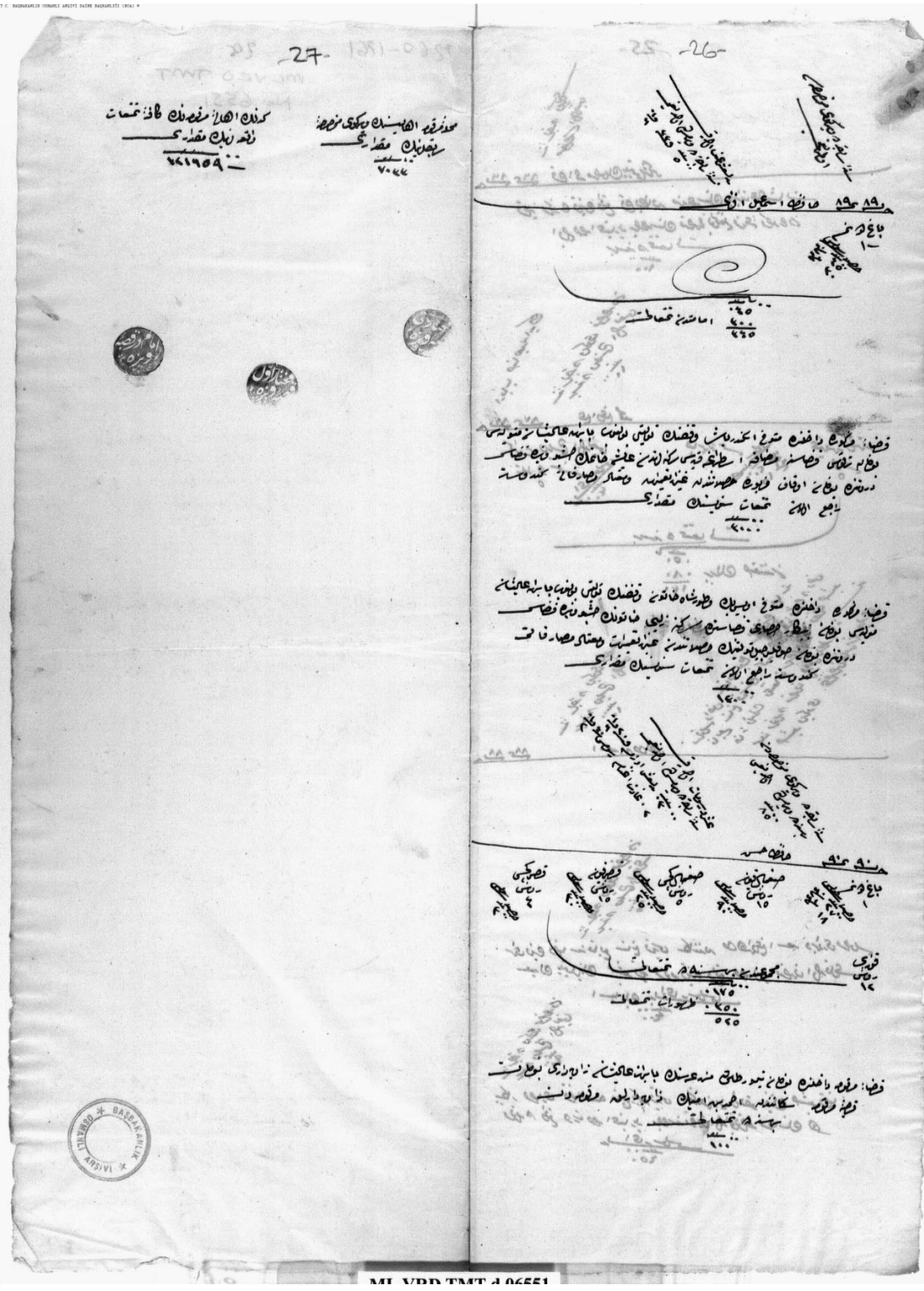

Ek 1: Vize'de Müslüman Hanelerin Bulunduğu Mahallelere Ait Temettuât Defterinin Son İki Sayfası (Derun-1 Kal'a Mahallesi) 


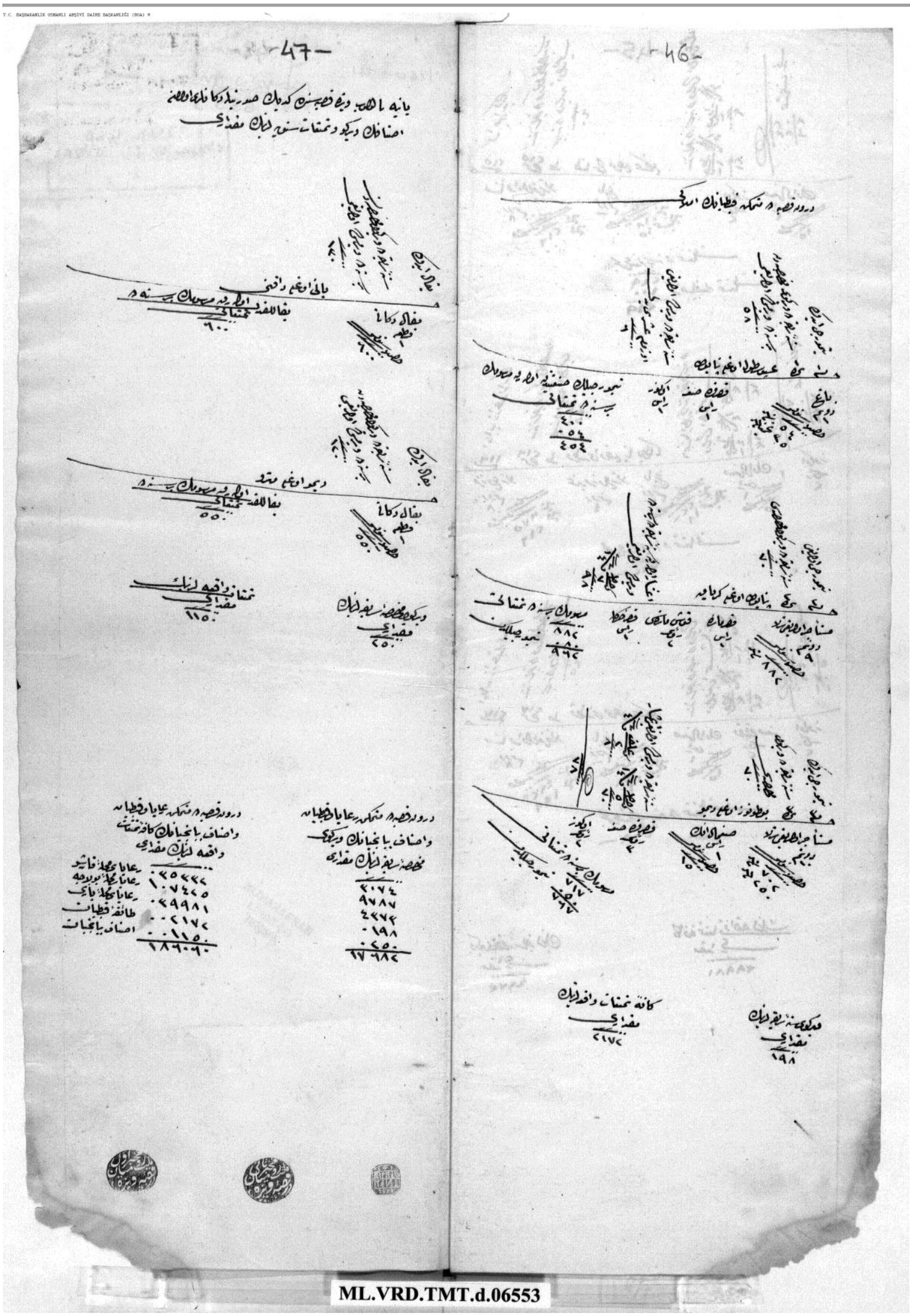

Ek 2: Vize'de Gayrimüslim Hanelerin Bulunduğu Mahallelere Ait Temettuât Defterinin Son İki Sayfası (Esnaflar ve Kıptîler) 